\title{
EFICIÊNCIA DE CULTIVARES DE SOJA NA ABSORÇÃO E UTILIZAÇÃO DE FÓSFORO
}

\section{ROBERTO WAGNER CAVALCANTI RAPOSO}

Engenheiro Agrônomo e Zootecnista

Orientador: Prof. Dr. TAKASHI MURAOKA

\begin{abstract}
Tese apresentada à Escola Superior de Agricultura "Luiz de Queiroz", Universidade de São Paulo, para obtenção do título de Doutor em Agronomia, Área de Concentração: Solos e Nutrição de Plantas.
\end{abstract}

P I R A C I C A B A

Estado de São Paulo - Brasil

Abril - 2003 


\section{Dados Internacionais de Catalogação na Publicação (CIP)}

DIVISÃO DE BIBLIOTECA E DOCUMENTAÇÃO - ESALQ/USP

\section{Raposo; Robérto-Wagher Caválcantị \\ Eficiência de cultivares de soja na absorção e utilização de fósforo / Roberto} Wagner Cavalcanti Raposo. - - Piracicaba, 2003.

$75 \mathrm{p}$.

Tese (doutorado) - Escola Superior de Agricultura Luiz de Queiroz, 2003. Bibliografia.

1. Absorção 2: Adúbaçăo fosfatada 3. Cerràdo 4. Fósforo 5. Soja 6. Variedades vegetais I. Título

CDD 633.34

"Permitida a cópia total ou parcial deste documento, desde que citada a fonte - 0 autor" 
A Deus, pois somente Ele realmente sabe os difíceis três últimos anos que passei.

Aos meus pais José Rapôso (in memorian) e Eneida.

\section{AGRADEÇO}

Aos meus filhos Allison, Ewerton, Annie a quem sempre procurei servir como exemplo na esperança que eles busquem os seus ideais com lisura...

À Graça pelo estímulo e apoio mesmo nos momentos de dificuldades...

Às minhas queridas irmãs Gladys, e. Sheila, meu cunhado Abelardo e sobrinhos Hugo e Victor, que estão distante, mas sempre dentro do meu coração...

\section{DEDICO}




\section{AGRADECIMENTOS}

Ao meu orientador, Professor Dr. Takashi Muraoka para o qual faltam-me até palavras diante da solicitude, presteza e competência.

Ao Professor Dr. Antonio Roque Dechen por ajudar em possibilitar o meu sonho.

Ao Centro de Ciências Agrárias da Universidade Federal da Paraíba pela oportunidade de realização da capacitação.

À Escola Superior de Agricultura "Luiz de Queiroz" e Centro de Energia Nuclear na Agricultura, da Universidade de São Paulo pela oportunidade.

A CAPES/PICDT pela concessão da bolsa de estudos.

À IAEA (International Atomic Energy Agency), Projeto CRP 10954/RO.

Aos funcionários da Biblioteca Central da ESALQ/USP e do CENA/USP especialmente, Eliana Maria Garcia e Silvia Maria Zinsly.

Aos colegas do curso José Lavres Júnior, João de Deus Gomes dos Santos Júnior pela ajuda e grande amizade desenvolvida, líderes do GEAP.

Às funcionárias do Laboratório de Fertilidade do Solo do CENA/USP, Marileuza A. Bassi Elias e Sandra T. Pereira dos Santos pelo auxílio nas análises laboratoriais.

Aos funcionários João Salvador, Maria Aparecida Soares, Henriqueta Fernandes, Suzineide Manesco, Cleusa Cabral, Miriam Raquel e Mônica Rossi pela amizade.

Aos amigos Gildemberg A. Leal Júnior, Antonio Carlos Cruz, Alessandro Riffel, Daniel Medeiros, Rodrigo Boaretto, Felipe C. A. Villanueva, Anderson R. Trevizan, Raquel Chagas, Vinicius I. Franzini, Silvana C. S. Bueno, Aline H. Maia, Maria Cláudia Sorreano, Ana Regina, Cristiane Cerqueira e Márcia Harder pelo apoio e amizade.

Ao Coral "Luiz de Queiroz" especialmente a maestrina Cíntia Pinotti, pela amizade e ensinamentos que marcaram minha vida.

Ao pessoal do xerox do CALQ pela presteza e paciência no atendimento. 


\section{SUMÁRIO}

Página

RESUMO …............................................................................ vii

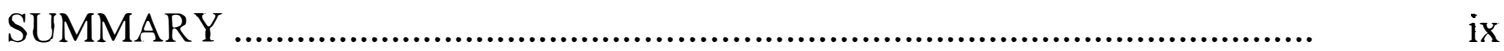

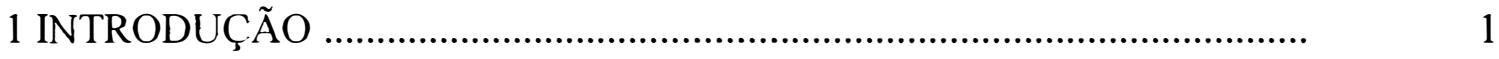

2 REVISÃO DE LITERATURA .......................................................... 3

2.1 Importância da cultura ......................................................................

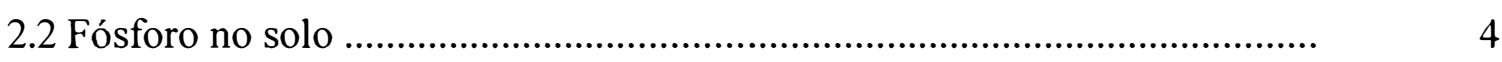

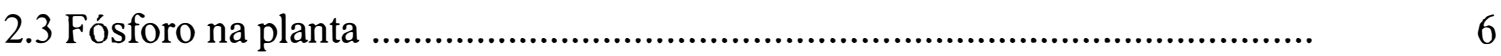

2.4 Fosfatase ácida e sua relação com a planta ................................................

2.5 Exsudação de ácidos orgânicos pelas raízes e mobilização de P na

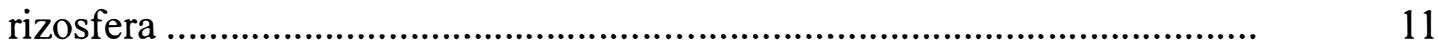

2.6 Fungos micorrízicos arbusculares como modificadores da eficiência de absorção e utilização de P ....................................................................... 13

2.7 Eficiência na absorção e utilização de P .................................................. 17

3 MATERIAL E MÉTODOS ................................................................. 21

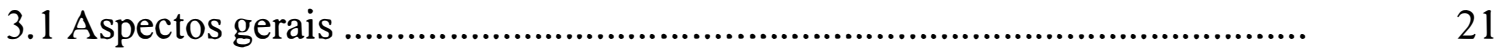

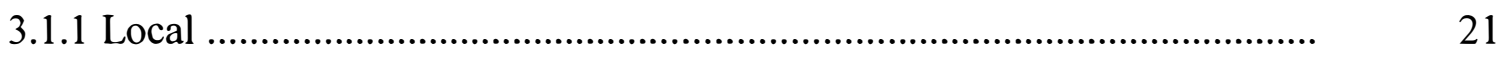

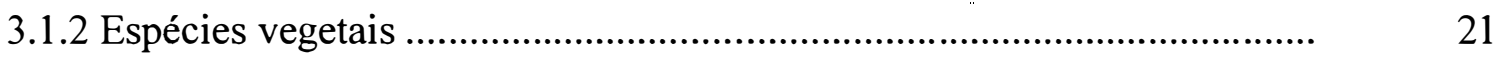

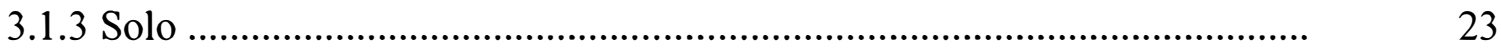

3.2 Experimento 1: Avaliação bioquímica das plantas: Fosfatase Ácida ......... 24

3.2.1 Condução do experimento .............................................................. 24

3.2.2 Determinação da atividade da fosfatase ácida ........................................ 24

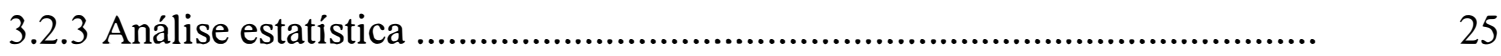


3.3 Experimento 2: Eficiência de absorção e utilização de $\mathrm{P}$ em cultivares de soja 25

3.3.1 Instalação e condução do experimento 26

3.3.2 Coleta do material vegetal e produção de matéria seca 26

3.3.3 Colonização das raízes pelos fungos micorrízicos arbusculares (FMAs) 26

3.3.4 Avaliação da eficiência de absorção de $\mathrm{P}$ 27

3.3.4.1 Concentração, conteúdo de $\mathrm{P}$ e contagem ${ }^{32} \mathrm{P}$ 27

3.3.4.2 Cálculo da atividade específica ( $\mathrm{S}$ ) 27

3.3.4.3 Cálculo da razão de eficiência radicular (RER) . 28

3.3.5 Avaliação da eficiência de utilização de $P$ 28

3.3.6 Análise estatística 29

4 RESULTADOS E DISCUSSÃO 30

4.1 Experimento 1: Avaliação bioquímica das plantas: Fosfatase Ácida 30

4.2 Experimento 2: Eficiência de absorção e utilização de $\mathrm{P}$ em cultivares de soja, do feijão guandu e do arroz

4.2.1 Produção de biomassa da parte aérea e raiz .............................................. 37

4.2.2 Concentração e conteúdo de P na parte aérea e na raiz ............................. 45

4.2.3 Cálculo da atividade específica (S) ......................................................

4.2.4 Razão de eficiência radicular(RER) ....................................................... 51

4.2.5 Índice de utilização de fósforo (IUP) …….............................................. 53

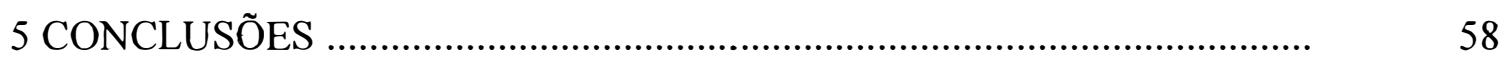

REFERÊNCIAS BIBLIOGRÁFICAS _..................................................... 59 


\title{
EFICIÊNCIA DE CULTIVARES DE SOJA NA ABSORÇÃO E UTILIZAÇÃO DE FÓSFORO
}

\author{
Autor: ROBERTO WAGNER CAVALCANTI RAPOSO \\ Orientador: Prof. Dr. TAKASHI MURAOKA
}

\section{RESUMO}

A adubação fosfatada corresponde à fração mais onerosa do custo de produção da cultura da soja. A obtenção de cultivares de soja eficientes na absorção e utilização de fósforo em condição sub-ótima de disponibilidade deste elemento contribui para aumentar o potencial produtivo da cultura. Trinta e dois cultivares de soja [Glycine $\max$ (L.) Merrill], recomendados para o cerrado, de ciclo precoce, semiprecoce, semitardio e tardio, foram avaliados em um Latossolo Vermelho Amarelo, distrófico, do cerrado, objetivando avaliar a eficiência de absorção e utilização de $\mathrm{P}$, utilizando-se parâmetros fisiológicos, químico/isotópico, bioquímico e microbiológicos. Dois experimentos foram instalados em casa de vegetação no CENA/USP, utilizando-se o delineamento em blocos casualizados com três repetições. No primeiro experimento avaliou-se a atividade da fosfatase ácida, biomassa da parte aérea e concentração de fósforo na folha diagnóstica. No segundo experimento avaliaram-se os cultivares de soja quanto à eficiência na absorção de P, utilizando como indicadores de absorção a razão de eficiência radicular e atividade específica de ${ }^{32} \mathrm{P}$ através da técnica de diluição isotópica de ${ }^{32} \mathrm{P}$ e, como indicador de eficiência de utilização, o índice de utilização de fósforo. Constataram-se diferenças entre os cultivares de soja, demonstrando que em 
condições sub-ótimas de disponibilidade de $\mathrm{P}$, os cultivares de soja apresentam comportamentos diferentes quanto à eficiência na absorção e utilização de fósforo. Os cultivares precoces, semiprecoces, semitardios e tardios apresentaram diferenças genotípicas na eficiência de absorção e utilização de fósforo não somente entre os grupos, mas também dentro dos grupos examinados. Os cultivares BRAS 97-7371 e IAC PL-1 destacaram-se entre os cultivares estudados na eficiência de absorção e utilização de P. A técnica da diluição isotópica de ${ }^{32} \mathrm{P}$ mostrou-se eficaz correlacionando-se negativamente com a atividade da fosfatase ácida. As variáveis percentagem de colonização micorrízica e razão de eficiência radicular não foram consistentes, e pouco contribuiu na avaliação dos cultivares quanto a absorção de fósforo. 


\title{
EFFICIENCY OF SOYBEAN CULTIVARS ON UPTAKE AND UTILIZATION OF PHOSPHORUS
}

\author{
Author: ROBERTO WAGNER CAVALCANTI RAPOSO \\ Adviser: Prof. Dr.TAKASHI MURAOKA
}

\section{SUMMARY}

The phosphate fertilization represents the most costly fraction of soybean crop production. The obtention of soybean cultivars efficient in absorption and utilization of phosphorus in soil of low available P status contributes for increasing productive potential of the crop. Thirty two soybean [Glycine $\max$ (L.) Merrill] cultivars (recommended for cerrado) of early, semi-early, semi-late and late cycle were grown in Distrophic red-yellow latosol (Typic Dystrarox) cerrado soil to evaluate their efficiency to absorb and utilize phosphorus by physiological, chemical/isotopical, biochemical and microbiological parameters. Two experiments were carried out in green house at CENA/USP (Centro de Energia Nuclear na Agricultura/University of S. Paulo), Brazil, using random bloc design with three replicates. In the first experiment acid phosphatase, shoot biomass and $\mathrm{P}$ content in the diagnostic leaf were considered for the cultivars evaluation. In the second experiment the root efficient ratio and the ${ }^{32} \mathrm{P}$ isotopic dilution technique were used as uptake indicators and $\mathrm{P}$ utilization index for $\mathrm{P}$ utilization efficiency. There were differences among the cultivars, showing that they behave differently in ability to absorb P in soil of low available P status. The early, semi-early, semi-late and late cultivars presented genotypic differences on uptake and utilization of 
P efficiency not only among the groups, but also within the examined group. The BRAS 97-7371 and IAC PL-1 cultivars were the best on the ability to absorb poorly available $\mathrm{P}$ and its utilization among the evaluated cultivars. The ${ }^{32} \mathrm{P}$ isotopic dilution technique showed efficient and correlated negatively with acid phosphatase activity. The variables mycorrhizal colonization percentage and root efficiency ratio were not consistent and little contributed for the comparison of soybean cultivars on the P uptake efficiency. 


\section{INTRODUÇÃO}

A soja é atualmente a oleaginosa mais importante cultivada no mundo e tem apresentado nas últimas cinco décadas, taxa de crescimento superior à de crescimento populacional, ocupando lugar de destaque na alimentação humana e animal.

No Brasil, a expansão da fronteiras agrícola, praticamente reativada na década de 70 , é hoje uma realidade, pois tomando o cerrado como exemplo, que passou de menos de 100.000 hectares de área colhida em 1975 (Câmara, 2000), para mais de 7,3 milhões de hectares na safra de 2002/03 (FNP, 2003), e isto só com soja.

A fase atual é de uma nova etapa de desenvolvimento da agricultura: a competitividade com outros mercados mundiais, não só com a soja, mas também com outros produtos agrícolas de exportação. É importante que os produtores conheçam, em detalhes, a cultura da soja, desde sua implantação nos primeiros anos, passando por adoção de tecnologias que propiciem a diminuição de seus custos de produção ao longo dos anos objetivando auferir lucros maiores. Nesse contexto, a busca da eficiência do uso do nutriente contido no fertilizante, notadamente o adubo fosfatado, contribui para a conquista de mais mercados, pois, com melhor produtividade, pode-se diminuir o custo de produção e ainda auferir maiores lucratividades.

O nutriente fósforo é geralmente encontrado em baixo teor na maioria dos solos brasileiros, limitando a produtividade agrícola da maioria das culturas, inclusive a soja. Além disso, é baixa a eficiência da absorção do fósforo tanto aplicado como o nativo nos solos em virtude das reações de fixação, tornando-o "indisponível" para as plantas. Assim, a adubação fosfatada corresponde à fração mais onerosa do custo de produção da cultura da soja. Alternativas para solucionar esses problemas seriam, além de melhorar técnicas de adubação e correção de solos, melhorar e selecionar cultivares mais 
tolerantes ao alumínio e mais eficientes na absorção e utilização de nutrientes, principalmente fósforo.

A capacidade de plantas desenvolverem-se em solos com baixo teor de fósforo disponível tem sido atribuída a diversos fatores, tais como diferenças na morfologia do sistema radicular, a densidade dos pêlos radiculares e excreções de ácidos orgânicos.

Diversas metodologias são utilizadas na determinação da eficiência de absorção de $\mathrm{P}$ pelas plantas, entre elas, a técnica de diluição isotópica utilizando 32P. A vantagem dessa técnica é a possibilidade de medir diretamente as diferenças entre plantas na capacidade de absorção de P que se encontra na forma menos disponível no solo..

O presente trabalho teve como finalidade avaliar a eficiência de absorção e utilização de $\mathrm{P}$ por cultivares de soja atualmente recomendados para o cerrado, utilizando-se de parâmetros químicos, bioquímicos e microbiológicos.

Este trabalho se baseou nas seguintes hipóteses: (1) Os cultivares classificados como precoces, semiprecoce, semitardios ou médios e os tardios apresentam diferenças nos índices de eficiência de P; (2) Os indicadores de eficiência de absorção (atividade específica do ${ }^{32} \mathrm{P}$ e razão de eficiência de $\mathrm{P}$ ) e o índice de utilização de $\mathrm{P}$ estudados, aliados à atividade da fosfatase ácida e colonização das raízes por fungos micorrízicos constituem avaliações que contribuem para a seleção de cultivares de soja; (3) Existe uma relação entre a atividade da fosfatase ácida e, pelo menos um dos índices de eficiência de absorção e utilização de $\mathrm{P}$ utilizados para a avaliação dos cultivares de soja. 


\section{REVISÃO DE LITERATURA}

\subsection{Importância da cultura}

Introduzida no Brasil no século XIX a soja (Glycine $\max$ L.) apresentava insignificante importância econômica em termos agrícolas até a década de 40 do século passado, e não participava nos levantamentos estatísticos oficiais (Tanaka \& Mascarenhas, 1992). O cultivo da soja passou a expandir-se no início da década de 70, a princípio nos Estados da região Sul e, posteriormente, avançando para os Estados das regiões Sudeste e Centro oeste, ajudando a aumentar as fronteiras agrícolas no Brasil (Câmara, 2000).

A produção de soja é altamente concentrada nos Estados Unidos, Brasil, Argentina e China, países responsáveis por quase $90 \%$ da produção total anual de 157 milhões de toneladas. É a mais importante oleaginosa cultivada no mundo e de maior expressão econômica no planeta, com teor de óleo compreendido entre 20 e $22 \%$ e apresentando alto teor de proteínas - de 40 a $42 \%$ nos cultivares mais difundidos características essas que levaram à formação de um complexo industrial destinado ao seu processamento (Câmara, 2000).

No Brasil, atualmente as regiões Sul e Centro-Oeste respondem por $90 \%$ da produção, sendo que nas áreas do cerrado, o clima, a topografia e a altitude são mais favoráveis para a obtenção de altas produtividades de culturas anuais do que nas áreas da região Sul. Além disso, o maior tamanho das propriedades no cerrado tende a permitir maiores ganhos de escala, diminuindo com o passar dos anos os custos de produção, fato este que não acontece nas regiões Sul e do Sudeste (FNP, 2002). A cultura da soja consome $25 \%$ do total de fertilizantes consumidos no País, sendo que dos três macronutrientes primários, o $\mathrm{P}$, embora o menos extraído, normalmente é o nutriente 
utilizado em maior quantidade, seja pelo baixo teor no solo, seja pela sua dinâmica nos solos tropicais (Vitti \& Trevisan, 2000).

\subsection{Fósforo no solo}

O fósforo no solo ocorre quase exclusivamente na forma de ortofosfato com a concentração de P total usualmente na faixa de $500-800 \mathrm{mg} / \mathrm{kg}$ de solo seco (Mengel \& Kirkby, 2001), havendo autores que ampliam esta faixa para 100 a $2000 \mathrm{mg} / \mathrm{kg}$ (Volkweiss \& Raij, 1977). A quantidade varia em função do material de origem, do grau de intemperismo, do teor de matéria orgânica e da reação do solo (Fassbender, 1986).

No entanto, menos de $0,1 \%$ desse total encontra-se na solução do solo (fator intensidade) com amplitude, entre 0,002 e $2 \mathrm{mg} \mathrm{L}^{-1}$ de $\mathrm{P}$ (Novais \& Smyth, 1999).

A medida que o P na solução do solo vai sendo exaurido pela absorção ou por outros fatores, o estoque de $\mathrm{P}$ trocável (P-Lábil) recomporá o $\mathrm{P}$ na solução do solo. Desta forma o P-Lábil, que indica o tamanho do estoque de $\mathrm{P}$, é denominado fator quantidade $(\mathrm{Q})$.

Estudos de calibração definiram o valor de $0,2 \mathrm{mg} \mathrm{L}^{-1}$ de $\mathrm{P}$ como a concentração de equilíbrio para o máximo crescimento das plantas (Beckwith, 1965). Contudo, as concentrações de equilíbrio para o crescimento máximo de milheto variaram inversamente à capacidade máxima de adsorção de P dos solos (Rajan 1973), esperandose menores valores de crescimento máximo em solos mais argilosos. Sendo assim observa-se que os solos diferem quanto à sensibilidade do P-Lábil a alteração do Psolução. A resistência do solo a mudar o P-Lábil, como conseqüência de alterações no Psolução ou vice-versa é denominada Fator Capacidade de P no solo (FCP) ou Poder Tampão de P do solo. Solos com maior FCP, como os mais intemperizados e argilosos (solos-drenos) mantêm mais constante o valor de P-solução(I), quando submetidos à adição ou à retirada de $\mathrm{P}$. A relação $\mathrm{Q} / \mathrm{I}$ é a medida do FCP. Nos solos com maior FCP (maior Q/I), a planta otimiza a menor concentração do P-solução que lhe é disponível, conseguindo produzir mais biomassa por unidade de $\mathrm{P}$ absorvido do que nos solos com 
menor FCP (arenosos, por exemplo), na condição de crescimento máximo das plantas (Novais \& Smyth, 1999).

No solo, o fósforo encontra-se associado à matéria orgânica (fósforo orgânico Po) ou fazendo parte de compostos inorgânicos (fósforo inorgânico - Pi) (Braga, 1980). As proporções dessas duas formas variam em função de fatores fỉsicos, químicos e biológicos do sistema solo (Fassbender et al., 1986).

Amostras de 17 solos brasileiros apresentaram Po total de 7 a $272 \mathrm{mg} \mathrm{kg}^{-1}$ representando de 13 a $47 \%$ do $\mathrm{P}$ total (Guerra et al., 1996). Os componentes de $\mathrm{P}$ orgânico (Po) no solo são identificados em extratos submetidos a cromatografia, à eletroforese e, mais recentemente, à espectrofotometria de ressonância nuclear magnética de ${ }^{31} \mathrm{P}\left(\mathrm{RNM}{ }^{31} \mathrm{P}\right)$ e podem ser divididos em: ortofosfatos de monoésteres, ortofosfatos de diésteres e fosfonatos (Novais \& Smyth, 1999).

A contribuição do fósforo orgânico para a nutrição das plantas é de difícil avaliação (Scivitaro, 1993). Os fosfatos orgânicos são considerados fontes potenciais de fósforo disponíveis para os vegetais, devendo ser mineralizados para que possam contribuir na nutrição vegetal (Igue et al., 1971 e Prezotto, 1979). Assim, as formas orgânicas de fósforo devem ser importantes para a nutrição das plantas cultivadas em solos tropicais recém-desmatados, devido à rápida decomposição da matéria orgânica (Barbosa Filho, 1986). A grande dificuldade é mensurar o fósforo oriundo da fração orgânica, das demais.

As formas de fósforo inorgânico derivam, quase que exclusivamente, de reações do ácido fosfórico com contribuintes minerais do solo (Henwall, 1957 e Fassbender 1986). As reações mais importantes ocorrem com cálcio, ferro e alumínio, e originam um grande número de compostos cujos principais representantes são a apatita, estrengita e variscita (Mengel \& Kirkby, 2001).

O fósforo ocluso é constituído principalmente por fosfatos de ferro e alumínio, recobertos por óxido de ferro precipitados resultantes da hidrólise de fosfatos e outros sais de ferro durante a intemperização química (Chang \& Jackson, 1957). 
Os fosfatos de alumínio fornecem mais fósforo às plantas que os fosfatos de ferro, sendo que os fosfatos de cálcio, por ocorrerem em pequena quantidade, pouco contribuem para a nutrição vegetal (Yuan et al., 1960; Ortega \& Guerreiro R. 1972; Mengel \& Kirkby 2001).

\subsection{Fósforo na Planta}

Fósforo é macronutriente da planta e participa com cerca de $2 \mathrm{~g} / \mathrm{kg}$ do peso da matéria seca (Schachtman et al., 1998). O P está envolvido em transdução de energia metabólica, no controle de reações de enzimas fundamentais, é intermediário na síntese de numerosos metabólitos e moléculas complexas (fosfolipídios, DNA, RNA, ATP, etc.). Conseqüentemente, as plantas não crescem bem sem um adequado suprimento deste nutriente, cujo processo de absorção é ativa, sendo o Pi absorvido predominantemente na forma monovalente mas os exatos mecanismos de transporte na membrana plasmática para o citoplasma ainda não estão claros, embora cotransportadores de $\mathrm{Pi}$ com um ou mais prótons seja a opção mais provável (Marschner, 1995; Mengel \& Kirkby 2001; Schachtman et al., 1998; Theodorou \& Plaxton, 1993).

Existem evidências de que o cotransporte de Pi através da membrana plasmática inclui outros elementos químicos, dentre eles cátions $\left(\mathrm{H}^{+}\right.$ou $\left.\mathrm{Na}^{+}\right)$, em virtude de ter sido observado a despolarização da membrana e acidificação do citoplasma em células de raízes deficientes em P. Em células animais, a absorção de Pi pela membrana plasmática normalmente envolve um cotransporte que inclui o $\mathrm{Na}^{+}$e não foi demonstrado em plantas superiores, contudo, acredita-se que a absorção de Pi através da membrana plasmática envolva cotransportador com $\mathrm{Na}^{+}$(Schachtman et al., 1998).

A transferência de Pi do citoplasma para o vacúolo envolve um diferente grupo de parâmetros termodinâmicos daqueles aplicados à membrana plasmática, principalmente por causa das concentrações milimolares no citoplasma e vacúolo, comparado às concentrações micromolares no solo. Poucas estimativas das 
concentrações de Pi citossólico e vacuolar são disponíveis. Contudo, quando plantas de milho desenvolvidas em concentração de Pi semelhante àquelas encontradas em solos, ou seja, $10 \mu \mathrm{M}$, a concentração estimada de Pi no citoplasma da célula da raiz foi maior do que a concentração vacuolar (Lee \& Ratcliffe, 1993). Concentração de Pi em citoplasma de células foliares de soja é também maior do que concentração de Pi no vacúolo, quando as plantas cresceram em soluções contendo 50 a $100 \mu \mathrm{M}$ Pi (Lauer et al, 1989). Uma vez que o potencial da membrana do vacúolo é em geral ligeiramente positivo com relação ao citoplasma sob condições normais, a transferência de Pi para o vacúolo não necessita ser feita com gasto de energia. Em plantas supridas com concentrações maiores de $\mathrm{P}$, o Pi parece estar próximo de um equilíbrio eletroquímico através do tonoplasto. Em um dos poucos estudos no qual o transporte no tonoplasto foi examinado, a absorção de Pi para dentro de vacúolos isolados de folhas de cevada com concentração adequada de $\mathrm{P}$, mostrou seguir um modelo monofásico, quase linear até uma concentração de $20 \mathrm{mM}$, e foi independente do suprimento de ATP (Mimura et al, 1990). Contudo, em vacúolos isolados de células deficientes em $P$, as taxas de absorção de Pi foram maiores e dependentes de ATP, apesar de que as baixas concentrações de Pi nos vacúolos favoreceriam a acumulação passiva de Pi. Isto implicaria na ativação ou inativação de um segundo transportador no tonoplasto em resposta à deficiência de Pi. A interpretação mais comum de estudos de cinética é que existem dois sistemas de absorção de $\mathrm{Pi}$, um com alta afinidade e atividade e que, ou aumenta ou não é contido pela deficiência de $\mathrm{Pi}$, e um com baixa afinidade e atividade que é constitutivo (Marschner 1995; Mengel \& Kirkby 2001; Schachtman et al., 1998). Recentes conhecimentos em biologia molecular de supostos transportadores em membrana plasmática e tonoplasto confirmam que as plantas possuem, pelo menos, quatro genes que codificam os transportadores de Pi (Schachtman et al., 1998).

A manutenção da estabilidade nas concentrações de Pi no citoplasma é essencial para muitas reações enzimáticas e esta homeostase ocorre graças às combinações entre os compartimentos ("pools") intracelulares de P e o transporte na membrana. Estes "pools" são classificados de diversas formas: 1) De acordo com sua localização em 
compartimentos físicos (citoplasma, vacúolo, apoplasto e núcleo); 2) Pela forma química de $\mathrm{P}$, tais como Pi, ésteres de $\mathrm{P}$, fosfolipídios e ácidos nucléicos; 3) De acordo com sua função fisiológica nas formas metabólica, reserva e cíclica. Os maiores avanços no mapeamento dos "pools" intracelulares vieram com a aplicação da espectroscopia de ressonância nuclear magnética (NMR) em tecidos vegetais, sendo no momento, a única maneira de medir diretamente os "pools" citoplasmático e vacuolar de Pi "in vivo" (Schachtman et al., 1998).

O P é móvel na planta e pode ser translocado tanto para a parte aérea como para o sistema radicular. O fosfato absorvido pelas raízes é translocado através do xilema principalmente para as partes da planta em crescimento (folha em expansão e em crescimento) (Fredeen et al, 1989).

A concentração de $\mathrm{P}$ na parte aérea parece regular também a translocação deste nutriente das raízes para a mesma. Durante os estágios iniciais de deficiência de P, onde o crescimento ainda não tenha sido afetado, geralmente as raizes retêm menos e translocam mais P que as plantas não deficientes (Cogliatti \& Clarkson, 1983). Em estágios mais avançados de deficiência, foi observado o inverso. Drew \& Saker (1984) mostraram que a baixa concentração de $\mathrm{P}$ na parte aérea pode aumentar consideravelmente a absorção e exportação de $\mathrm{P}$ pelas raízes, as quais têm alta concentração de $\mathrm{P}$. Estes autores sugeriram ainda, que a absorção de $\mathrm{P}$ através do plasmalema é regulada pelo efluxo de $\mathrm{P}$ do simplasto para o xilema, sendo a última etapa controlada pela concentração de fosfato ou éster-fosfato originados da parte aérea, reciclados via floema para as raízes.

Em plantas bem supridas em $\mathrm{P}$ a maior parte do Pi absorvido pelas raizes é transportada no xilema para as folhas mais novas. As concentrações de Pi no xilema variam de $1 \mathrm{mM}$ em plantas deficientes em P a $7 \mathrm{mM}$ em plantas crescidas em soluções contendo $125 \mu \mathrm{M}$ de Pi (Mimura et al., 1996). Há também uma significativa retranslocação do Pi no floema das folhas mais velhas para os pontos de crescimento da parte aérea e da parte aérea para os pontos de crescimento da parte aérea e da parte aérea para as raízes. Em plantas deficientes em Pi, a restrição no suprimento de Pi da raiz para 
a parte aérea via xilema é suplementado pelo aumento na mobilização de $\mathrm{P}$ armazenado nas folhas mais velhas e retranslocação tanto para as folhas mais novas como para as raízes em crescimento. Este processo envolve tanto a exaustão de Pi armazenado como a quebra de $\mathrm{P}$ orgânico nas folhas mais velhas (Schachtman et al., 1998). Segundo Jeschke et al. (1997), as plantas com fome de $\mathrm{P}$ translocam metade do Pi translocado da parte aérea para as raízes via floema, sendo então transferido para o xilema reciclando de volta para a parte aérea. No xilema o $\mathrm{P}$ é transportado quase que exclusivamente como $\mathrm{Pi}$, enquanto que significativa quantidade de $\mathrm{P}$ orgânico são encontrados no floema (Schachtman et al., 1998). Outra função importante de P é na distribuição de matéria seca entre as raízes e a parte aérea. Numa condição de deficiência de $\mathrm{P}$, a maior relação raiz / parte aérea é resultante de uma alteração morfológica que contribui para aumentar a superfície radicular de absorção (Aung, 1974). Nesta condição de deficiência de P as raízes transformam-se em forte dreno de carboidratos, causando limitação no crescimento da parte aérea do que da raiz (Clarkson, 1985).

$O$ fósforo está envolvido no controle de reações de enzimas fundamentais e na regulação de caminhos metabólicos, especialmente as formas inorgânicas como o Pi ou o pirofosfato (PPi), bem como os açúcares fosforilados, têm grande influência na regulação metabólica das plantas (Theodorou \& Plaxton, 1993; Bieleski \& Ferguson, 1983).

\subsection{Fosfatase ácida e sua relação com a planta}

Compreender a maneira como o fósforo se comporta no aspecto de disponibilidade para as plantas sem se conhecer como as fosfatases atuam, torna-se incompleta. Cerca de 30 a 70\% do P total do solo encontra-se na forma orgânica e esta fração é hidrolisada liberando Pi para as plantas. Esta reação é catalisada pela atuação de enzimas genericamente denominadas fosfatases proporcionando a liberação de Pi para as plantas (Novais \& Smyth, 1999). 
Toda enzima apresenta seu $\mathrm{pH}$ ótimo e as fosfatases são classificadas em fosfatases ácidas, produzidas por plantas e microrganismos, com pH ótimo na faixa de 46, e fosfatases alcalinas, produzidas por bactérias e fungos, com pH ótimo entre 9 e 11 (Stevenson, 1986).

A rápida identificação do desbalanço mineral em plantas é vital se medidas corretivas forem tomadas antes da produção e qualidade das culturas serem afetadas. Os métodos convencionais para análise mineral dos tecidos vegetais são geralmente demorados, e os resultados, muitas vezes, podem levar a interpretações equivocadas (Besford, 1980; Bovi et al., 1998). A utilização de parâmetros bioquímicos, especialmente a medida da atividade de enzimas que possam refletir o nível de determinado nutriente no tecido vegetal, merece atenção por constituir, em alguns casos, um procedimento rápido e sensível no diagnóstico precoce do desequilíbrio e da deficiência de nutrientes minerais. Por constituir um teste rápido e sensível do estado do P na planta, foi sugerido por Besford (1979a, b) a utilização da atividade da fosfatase ácida como indicador bioquímico da defíciência de P nas culturas. Segundo Besford (1979c), foram induzidos desbalanços de 15 nutrientes em plantas de tomate e somente a deficiência de P provocou, de forma significativa, um aumento da atividade da fosfatase ácida nas folhas, por isso tem sido sugerido que esta enzima poderia ser utilizada para detectar deficiência de $\mathrm{P}$ nestas plantas. Numerosas referências têm indicado a relação existente entre a atividade da fosfatase ácida e os teores de fósforo nos tecidos nas espécies vegetais Licopersicon esculentum Mill (Hewitt \& Tathan, 1960; Besford, 1979a,b), Oryza sativa L (Zaini \& Mercado, 1985), Saccharum officinarum L (Silva \& Basso, 1993), Triticum aestivum L (McLachlan, 1982; McLachlan et al., 1987), Phaseolus vulgaris L e Vigna unguiculata L Walp (Fernandez \& Ascencio, 1994; Ascencio, 1994), Cajanus cajan L e Gossypium hirsutum L (Ascencio, 1994), Cucumis sativus L (Besford, 1978) e Bactris gasipaes Kunth (Bovi et al., 1998).

Furlani \& Machado (2002) tem apontado diferenças intra-específicas na atividade da fosfatase ácida, por exemplo, linhagens de sorgo eficientes apresentaram menor atividade enzimática em raízes intactas sob condições de baixa concentração de 
$\mathrm{P}$, quando comparada às ineficientes. Em híbridos de milho, um precoce e outro tardio, observou-se aumento na atividade enzimática das folhas de ambos sob deficiência de $\mathrm{P}$ e também uma relação inversa entre a produção de matéria seca de parte aérea e a atividade dessa enzima, com o híbrido precoce, de menor produção de matéria seca, apresentando maior atividade, ao contrário do outro, tardio, de maior produção e menor atividade. Em folhas de genótipos de feijoeiro eficiente e ineficiente a baixa disponibilidade de $\mathrm{P}$, e linhagens $\mathrm{F}_{5.10}$ obtidas do seu cruzamento, a deficiência de $\mathrm{P}$ aumentou significativamente a atividade da fosfatase ácida nas folhas, porém esse aumento foi maior no genótipo ineficiente. Diante desses fatos percebe-se a existência de duas correntes opostas: (1) plantas adaptadas a condições de baixa disponibilidade de $\mathrm{P}$ (eficientes na aquisição ou utilização de $\mathrm{P}$ ) possuem elevada atividade da fosfatase ácida nas raízes (ou nas folhas), como sinal de sua competência para hidrolisar e remobilizar o $\mathrm{P}$ do solo pela secreção desta enzima pelas raízes (ou de outras partes mais velhas da planta); e (2) plantas adaptadas a condições de baixa disponibilidade de $\mathrm{P}$ (eficientes na aquisição ou utilização de $\mathrm{P}$ ) possuem menor exigência em $\mathrm{P}$ e conseqüentemente apresentam menor atividade da fosfatase ácida em situação de estresse do nutriente, comparativamente às plantas não adaptadas ou mais exigentes, sendo a atividade da fosfatase ácida um indicador da severidade do estado de deficiência de $\mathrm{P}$ da planta. Ainda, segundo esses mesmos autores, quanto mais estressada a planta, maior a atividade da fosfatase, sinal de menor adaptação.

\subsection{Exsudação de ácidos orgânicos pelas raízes e mobilização de P na Rizosfera}

Os ácidos orgânicos constituem um dos principais componentes dos exsudatos de raízes e estão envolvidos na mobilização de nutrientes dentro da rizosfera (Gardner et al., 1983; Hoffland et al., 1989; Hoffland, 1992; Ström et al., 1994; Marschner, 1995; Ström 1997; Farrar and Jones, 2000). Devido à falta de evidências diretas de que os ácidos orgânicos potencializam os mecanismos de mobilização, evidências indiretas sugerem um papel central em alguns processos da rizosfera envolvendo reações de 
complexação de metais (Jones, 1998). Um exemplo claro disto é a liberação de ácidos orgânicos pelas raízes expostas a níveis potencialmente tóxicos de $\mathrm{Al}^{3+}$, que correlaciona-se com o grau de tolerância ao Al (Ryan et al., 2001).

A liberação de ácidos orgânicos pelas raízes tem sido implicada como mecanismo que as raízes apresentam aumentando a disponibilidade de nutrientes pouco solúveis do solo tais como $\mathrm{P}, \mathrm{Zn}, \mathrm{Fe}$ e Cu (Marchner, 1995; Jones, 1998). Além disso, o $\mathrm{P}$ apresenta baixo potencial de difusão em comparação a outros nutrientes com alta demanda pela planta, como por exemplo, $\mathrm{NO}_{3}^{-}, \mathrm{K}^{+}$(Barber, 1995). Em conseqüência, as plantas têm desenvolvido uma série de mecanismos para tornar o P mais disponível, incluindo a formação da simbiose micorrízica, produção de pêlos radiculares e a liberação de exsudatos (fosfatase, ácidos orgânicos).

Tornou-se universalmente aceito que os ácidos orgânicos causam uma mobilização significativa de P na rizosfera (Marchner, 1995). Contudo, existe pouca evidência de que a maioria das plantas, sob deficiência de $\mathrm{P}$, liberam mais ácidos orgânicos de suas raízes em comparação com plantas com suficiência em P (Hoffland et al., 1989; Imas et al., 1997). A base genética de exsudação se existe, permanece desconhecida e até o presente momento o significado deste efluxo permanece controverso (Jones, 1998). Um estudo "in vivo" utilizando plantas de milho demonstrou que os ácidos orgânicos, notadamente o oxálico, aumentou significativamente a acumulação de ${ }^{33} \mathrm{P}$ na parte aérea, embora, a magnitude de mobilização de $\mathrm{P}$ dependa do contexto em que a planta se encontra (Ström et al., 2002). A soja é tida como planta não secretora ou pouco secretora de ácidos orgânicos diferentemente do guandu (Cajanus cajan L.) e o tremoço branco (Lupinus albus) que secretam grande quantidade de ácidos orgânicos, entre eles, o ácido cítrico pelos protéoides das raízes do tremoço branco e ácido malônico e piscídico pelo feijão guandu (Otani et al., 1996; Hocking \& Randal, 2001).

Plantas que absorvem $\mathrm{N}$ preferencialmente como $\mathrm{NO}_{3}{ }^{-}$tendem a aumentar o $\mathrm{pH}$ da rizosfera, enquanto plantas que preferem $\mathrm{NH}_{4}^{+}$ou utilizam também $\mathrm{N}_{2}$ simbiótico reduzem-no, acarretando diferenças de 1-2 unidades entre a rizosfera e o solo (Riley \& 
Barber, 1971), que podem se estender até $4 \mathrm{~mm}$ da superfície radicular (Gahoonia et al., 1992). Plantas de soja adubadas com nitrogênio na forma de $\mathrm{NH}_{4}^{+}$apresentaram maior conteúdo de $\mathrm{P}$ do que aquelas adubadas com $\mathrm{NO}_{3}^{-}$, o que foi atribuído principalmente ao efeito da nutrição amoniacal na redução do pH da rizosfera (Riley \& Barber, 1971). Soja e alfafa (Medicago sativa $L$ ), utilizando $\mathrm{N}_{2}$ simbiótico, absorveram mais cátions que ânions, causando uma acidificação do meio e aumentando a disponibilidade de P de rochas fosfatadas (Aguilar \& Diest, 1981).

\subsection{Fungos micorrizicos arbusculares como modificadores da eficiência de absorção e utilização de $P$}

Em ecossistemas naturais, mais de $80 \%$ das plantas superiores vivem em associação com fungos micorrízicos arbusculares (FMAs) (Smith \& Read, 1997). Estas interações mutualísticas evoluíram por cerca de muitas centenas de milhões de anos, sendo que o sistema radicular das plantas mais primitivas era associado com o ancestral do FMA (Redeker et al., 2000). Atualmente as simbioses entre FMAs e as plantas podem ser encontradas em ecossistemas de todo o mundo, onde elas afetam a biodiversidade vegetal e o funcionamento do ecossistema (Newsham et al., 1995; Van der Heijden et al., 1998). Os mecanismos que os FMAs utilizam na contribuição para a nutrição mineral das plantas, principalmente de fósforo, não são completamente compreendidos, mas é muito difundido o relato sobre o benefício dos FMAs neste aspecto, resultando em um melhor estado fitossanitário e vigor da planta (Smith \& Read, 1997; Van der Heijden et al., 1998). Estes atributos também tornam esta relação simbiótica um componente essencial da agricultura sustentável (Jeffries, 1987). Os FMAs são biotróficos obrigatórios que colonizam as raízes das plantas para obter carbono da planta. Além de crescer dentro do córtex da raiz, eles desenvolvem um extensivo micélio extra-radicular no ambiente edáfico. As fases de crescimento intraradicular e extra-radicular são um único "continuum" e é por esta via que o fungo é hábil 
em translocar fosfato do solo para o interior do sistema radicular, onde é liberado para a planta (Jakobsen, 1995; Harrison, 1997; Smith et al., 2001).

O processo de desenvolvimento da simbiose varia com a planta e as espécies de fungos envolvidos (Smith \& Smith, 1997). Na maioria das espécies cultivadas, o fungo cresce inicialmente nos espaços intercelulares da raiz e então se diferencia dentro das células corticais, formando uma hifa duplamente ramificada chamada de arbúsculos (Bonfante-Fasolo, 1984). Embora localizado fisicamente dentro da célula cortical, os arbúsculos permanecem separados do citoplasma da planta por uma extensão da membrana plasmática, chamada membrana periarbuscular. Este envolvimento dos arbusculos também resulta na formação de um novo espaço apoplástico entre a membrana periarbuscular e o arbúsculo, chamado espaço periarbuscular (Harrison, 1997). A membrana plasmática da planta amplia-se 10 vezes ao redor do arbúsculo (Alexander et al., 1989), e esta interface estendida, conjugada com o alto conteúdo de fosfato destas células (Cox et al., 1980), apóia a sugestão que o transporte de fosfato entre o fungo e a planta ocorre neste novo espaço apoplástico.

Embora estudos com radiotraçador tenham demonstrado que o fosfato move-se do solo, via hifas do fungo, para a planta (Sanders \& Tinker, 1971; Pearson \& Jakobson, 1993), relativamente pouco é conhecido sobre proteínas que transportam o fosfato.

Os fatores que afetam a absorção e utilização de $\mathrm{P}$ pelas plantas têm sido revisados em várias ocasiões (Barber, 1995; Clarkson 1985, Koide, 1991). Dentre este fatores citam-se, por exemplo, a taxa de crescimento da raiz (ou comprimento radicular) e o raio radicular, que afetam o volume de solo explorado e são mais importantes do que as características cinéticas do processo de absorção (Km e Vmax). Muitas das espécies de plantas não micorrízicas desenvolveram estratégias que aumentam a aquisição de nutrientes, incluindo a formação de aglomerados de raízes, pelos radiculares longos ou numerosos e produção de ácidos, enzimas ou agentes quelatizantes (Hedley et al., 1982). A formação de uma extensiva rede de micélios micorrízicos no solo também aumenta o volume de solo acessível às plantas e a absorção por estes micélios efetivamente esgota o P do solo e aumenta o influxo ou taxa de absorção específica de nutrientes pelas raízes 
(Kothari et al.; 1991). Além disso, espécies ou genótipos que apresentam dependência micorrízica para adequada aquisição de nutrientes apresentam provavelmente, um sistema radicular com baixa eficiência de exploração (Azcon \& Ocampo, 1981), embora esta correlação nem sempre seja observada (Crush \& Carradus, 1980).

Em plantas com dependência micorrízica, a colonização de suas raízes aumenta a eficiência de absorção de P e Zn do solo (Smith \& Read, 1997). O envolvimento das micorrizas na absorção de nutrientes pode explicar algumas discrepâncias entre a absorção de P prevista e observada em solos pobres em P (Smith et al., 2001). A previsão efetiva dos benefícios potenciais da absorção de $\mathrm{P}$ através das micorrizas em condições de campo é um pré-requisito para o desenvolvimento de estratégias de manejo e programas de melhoramento para a maximização da eficiência da simbiose (Smith et al., 1992).

A contribuição do fungo micorrízico na absorção pode ser estimada comparandose o influxo (absorção por unidade de comprimento de raiz na unidade do tempo) em plantas micorrizadas e não micorrizadas. Esta absorção é maior em plantas jovens crescendo em solos severamente deficientes em P. Contudo, mesmo quando o P no solo é adequado para o crescimento de plantas não micorrizadas (de modo que a resposta de crescimento de plantas micorrizadas não ocorre), pode ainda haver uma contribuição para a absorção tão abrangente quanto a injeção persistir no sistema radicular (Smith et al., 1986; Smith \& Gianinazzi-Pearson, 1988).

$\mathrm{O}$ aumento da eficiência de absorção de $\mathrm{P}$ pelas plantas micorrizadas freqüentemente leva a concentrações críticas de $\mathrm{P}$ maiores nos tecidos. Este fato pode refletir acumulação de luxo em plantas jovens e pode também ser uma conseqüência da limitação de carbono (Stribley et al., 1980). A taxa de eficiência de P baseada na relação entre peso da parte aérea e concentração de P na parte aérea (ou seja, determinação da concentração crítica para $90 \%$ do máximo peso da parte aérea) pode desta forma, ser afetada pela colonização micorrízica, se as plantas são colhidas antes que o aumento da absorção de $\mathrm{P}$ refletir no incremento do crescimento da planta ou, se o dreno de $\mathrm{C}$ para o fungo afetar a produção de matéria seca. 
Várias são as hipóteses propostas para se explicar o mecanismo pelo qual o P no interior da planta inibe o processo de formação das associações micorrízicas. Mediante o conhecimento teórico de outros sistemas biológicos, Woolhouse (1975) propôs um mecanismo envolvendo as fosfatases ácidas e as lectinas. Em plantas normais, sem deficiência de $\mathrm{P}$, a lectina, uma glicoproteína rica em hidroxiprolina, combinaria com o $\mathrm{N}$-acetilglicosamina da parede do fungo e inibiria o crescimento do tubo germinativo. Ao contrário, as plantas deficientes em $\mathrm{P}$ induziriam a produção e o acúmulo de fosfatases não específicas nas raízes. As fosfatases, quando presentes em maior quantidade nas plantas deficientes em $\mathrm{P}$, combinariam com as lectinas, modificando-as e impedindo a combinação com o $\mathrm{N}$-acetilglicosamina da parede celular do fungo, o que possibilitaria o estabelecimento da associação.

Uma outra hipótese, envolvendo a permeabilidade da membrana, foi proposta por Ratnayake et al (1978). Esses autores propuseram que altos níveis de $\mathrm{P}$ na planta resultam em aumento da biossíntese de fosfolipídios, tornando a membrana celular menos permeável a carboidratos e a aminoácidos, os quais seriam necessários ao fungo para o processo de colonização. Essa hipótese baseou-se na verificação de que as raízes de sorgo e citrus, em plantas com alto teor de $\mathrm{P}$, apresentaram-se com maiores níveis de fosfolipídios, menor permeabilidade da membrana citoplasmática ao efluxo de $86 \mathrm{Rb}$ e menor exsudação de açúcares e aminoácidos. Essa menor quantidade de exsudatos, contendo carboidratos e aminoácidos, não seria suficiente para sustentar o processo de colonização. Embora os estudos de Graham et al. (1981) tenham corroborado essa hipótese, algumas considerações sobre a metodologia usada nesses trabalhos, em que se estudou o efeito de doses de $\mathrm{P}$ sobre a permeabilidade de membrana, devem ser feitas. A primeira seria sobre o uso do superfosfato como fonte de $\mathrm{P}$, não se mencionando a compensação da quantidade de cálcio nas diferentes doses de fósforo. O cálcio é importante para a integridade da membrana e, portanto, para a sua permeabilidade (Marschner, 1995). É sabido também que a maior absorção de fosfato (Pi), por Saccharomyces cereviseae, é acompanhada pela absorção do íon $\mathrm{K}^{+}$, provavelmente em razão do necessário balanço de carga (Beever \& Burns, 1980). Assim sendo, o menor 
efluxo de ${ }^{86} \mathrm{Rb}$ nas raízes, observado por aqueles autores poderia ser, na verdade, uma conseqüência da interação entre $\mathrm{Pi}$ e $\mathrm{K}^{+}$durante a absorção.

\subsection{Eficiência na absorção e utilização de $\mathbf{P}$}

É bem conhecido, que as espécies de plantas apresentam diferentes capacidades de absorver nutrientes (Rorinson, 1968; Scott Russel et al., 1958).

As publicações de Hunt(1973), Jones et al.(1989), Batten(1992), Yan et al.(1995); Fageria(1998), Helyar(1998), Araújo(2000) e Zhu et al.(2002) tratam de revisões de eficiência de absorção de fósforo. A eficiência de absorção é definida freqüentemente em termos da absorção total do nutriente em $\mathrm{mg} / \mathrm{planta}$, influxo ou taxa de absorção específica em mol cm $\mathrm{cm}^{-1} \mathrm{~s}^{-1}$ ou mol g $\mathrm{s}^{-1}$ (Smith et al., 1992).

Comparando-se gramíneas e leguminosas, observa-se que as primeiras são mais competitivas no crescimento sob baixo teor de $\mathrm{P}$, contudo, as leguminosas apresentam maior influxo de $\mathrm{P}$, e um crescimento radicular mais lento. A eficiência de absorção de $\mathrm{P}$ está relacionada à maior produção de área radicular, quando ocorre a maior limitação na difusão de P no solo, do que da velocidade de absorção radicular (Araújo 2000).

A limitação do crescimento vegetal determinada por alguns nutrientes, principalmente $\mathrm{N}$ e o $\mathrm{P}$, transformam as raízes em consumidoras de carboidratos, limitando o crescimento da parte aérea fazendo assim com que a relação raiz: parte aérea aumente. Isto se deve ao $\mathrm{P}$ orgânico nas raízes apresentar-se em maior proporção que o $\mathrm{Pi}$, o qual estará menos disponível para o transporte para a parte aérea (Araújo 2000). Espécies com alta eficiência de absorção de $\mathrm{P}$ apresentaram elevado influxo de $\mathrm{P}$ ou elevada razão raiz: parte aérea, enquanto que espécies com baixa eficiência apresentavam baixo influxo e baixa razão raiz: parte aérea (Föhse et al., 1988).

Os parâmetros normalmente usados para avaliação da eficiência de absorção de $\mathrm{P}$ pelas espécies vegetais e cultivares dentro das espécies são: conteúdo de $\mathrm{P}$ acumulado por planta que permite apenas uma comparação preliminar de genótipos; razão de eficiência radicular (RER) definido como a quantidade de $\mathrm{P}$ absorvida pela planta por 
unidade de peso e raiz, reflete a habilidade da planta em obter $\mathrm{P}$ do solo, ainda pouco relatado em trabalhos segundo Batten (1992); taxa de acumulação absoluta (TAA) que descreve a velocidade de acumulação do nutriente (ex: mg P/dia) por unidade de tempo, atividade específica de ${ }^{32} \mathrm{P}$ entre outros (Araújo, 2000; Fernandes, 2001).

Hocking et al. (1997) comparando a habilidade de diferentes espécies vegetais em acessar P não oriundo do fertilizante, através da técnica de diluição isotópica de ${ }^{32} \mathrm{P}$, concluíram que o tremoço branco foi a espécie mais eficiente comparando-se com canola, tremoço azul, guandu, soja, girassol e trigo. A soja, neste experimento, apresentou alta atividade específica (S), apresentando a menor eficiência. Esta técnica apresenta a vantagem de medir diretamente as diferenças entre plantas na capacidade de absorção de $\mathrm{P}$, não dependendo diretamente de nenhum parâmetro citado anteriormente. A técnica de diluição isotópica, segundo Di et al. (2000), tem ganhado adeptos na determinação das transformações de nutrientes no sistema solo-planta, baseando-se na abundância natural do isótopo em estudo ou na atividade específica (S) quando são utilizados radioisótopos, que é o caso do ${ }^{32} \mathrm{P}$. A atividade específica $(\mathrm{S}) \mathrm{de}{ }^{32} \mathrm{P}$, segundo Hocking et al. (1997) é calculada pela relação entre a atividade de ${ }^{32} \mathrm{P}(\mathrm{CPM})$ e a quantidade total de $\mathrm{P}$ na planta, em microgramas, com a unidade ficando em, por exemplo, CPM (contagens por minuto) $\mu \mathrm{g}^{-1}$. Plantas com menor atividade específica possuem maior quantidade de $\mathrm{P}$ proveniente da fonte menos solúvel do solo, sendo mais eficientes em absorver o nutriente do solo.

$\mathrm{O}$ equilíbrio entre a quantidade total de $\mathrm{P}$ absorvido e o efeito do nutriente no metabolismo e na produção de biomassa determinará a eficiência com que este nutriente é utilizado. A eficiência de utilização é definida como produção total de biomassa por unidade do nutriente absorvido (p. e. mg biomassa $\mathrm{mg}^{-1} \mathrm{P}$ ) ou por nutriente aplicado no solo (Siddiqi \& Glass, 1981; Smith et al. 1992). Na literatura, essa razão tem sido denominada de quociente de utilização, coeficiente de utilização e razão de eficiência. Quando se estuda este coeficiente de utilização do P, em função da disponibilidade, geralmente se obtém uma relação inversa (Pereira, 1986). Isto indicaria que plantas crescidas a menores níveis de P são mais eficientes. Entretanto, plantas crescidas em 
baixo P crescem pouco por causa da severa deficiência. Esta aparente alta eficiência de uso de P na produção de matéria seca resulta, segundo Jarrell \& Beverly (1981), da diluição do $\mathrm{P}$ pelo limitado crescimento. $\mathrm{O}$ menor coeficiente de utilização nas maiores doses de $\mathrm{P}$ resulta da contínua absorção de $\mathrm{P}$ e do conseqüente armazenamento do Pi no vacúolo, sem que haja proporcional aumento de biomassa. Siddiqi \& Glass (1981) sugeriram que, na avaliação da eficiência de utilização, deve-se considerar a concentração total do nutriente contido na biomassa. Esse argumento é baseado no conceito de que a concentração de um nutriente essencial deve estar acima de um nível crítico para sua ótima atuação no metabolismo, o que resultará em crescimento máximo. Considerando que as folhas são as principais fontes de fotoassimilados que resultarão em crescimento, a expressão da eficiência, com base na concentração do nutriente neste órgão, pode ser considerada mais apropriada. Após a absorção de $\mathrm{P}$ pelas raízes, a eficiência de utilização de $\mathrm{P}$ pode contribuir para as diferenças no crescimento vegetal em condições de limitação do nutriente.

As diferenças de produção de biomassa em genótipos de feijoeiro sob baixo teor de $\mathrm{P}$ estiveram associados à eficiência de utilização (Gabelman \& Gerloff, 1983). Cultivares de feijoeiro diferenciam no teor de $\mathrm{P}$ na folha e na taxa de utilização específica de $\mathrm{P}$ sob suprimento limitado de $\mathrm{P}$, mas não sob suprimento adequado; desta forma, a utilização de $\mathrm{P}$ pode ser importante componente físiológico na seleção de genótipos tolerantes à baixa disponibilidade de $\mathrm{P}$ no solo (Araújo, 2000), embora outros pesquisadores tenham proposto que a variação genética existente para eficiência em feijoeiro seria associada principalmente à variação na eficiência de absorção e não na eficiência de utilização (Lynch \& Beebe, 1995).

Os resultados disponíveis na literatura não permitem definir qual o componente fisiológico mais importante na produtividade vegetal sob suprimento limitado de $\mathrm{P}$, a eficiência de absorção ou a eficiência de utilização (Araújo 2000). A maximização da eficiência de utilização de $\mathrm{P}$ é equiparada com a minimização da taxa de fertilização fosfatada requerida para manter economicamente, ótimo estado de fertilidade do solo em termos de P, de um sistema (Helyar, 1998). O aumento da eficiência de utilização de P 
pode ser feito através do desenvolvimento de cultivares através da seleção de características que favoreçam a demanda da planta tais como: maturação tardia, aumento da longevidade das raízes finas e aumento da capacidade de solubilização de $\mathrm{P}$, além do índice superfỉcie radicular por unidade de P requerido (Helyar, 1998). Vários são os indicadores na avaliação da eficiência de utilização de $\mathrm{P}$, com grande discrepância na terminologia gerando confusão de alguns índices (Lauchli, 1987; Bailian et al., 1991; Araújo 2000). Os indicadores mais utilizados são: produção de biomassa, quociente de utilização, índice de utilização, taxa de utilização, nível crítico interno, índice de colheita, dentre outros (Araújo, 2000; Batten 1992; Shah et al., 2001).

Estudos de eficiência nutricional com dois cultivares de soja foram realizados em solução nutritiva e observou-se que cultivares mais eficientes na modulação dos parâmetros cinéticos $\mathrm{V}_{\text {máx }}, \mathrm{K}_{\mathrm{m}}$ e $\mathrm{C}_{\min }$ mostraram maior variação na quantidade de $\mathrm{P}$ translocada das raízes para a parte aérea, em resposta à sua condição nutricional interna (Martinez et al., 1993). Vinte e nove cultivares de soja foram avaliados e classificados quanto à resposta a concentrações de P em solução nutritiva, por Furlani et al. (2002) observando-se haver alta correlação entre a matéria seca(MS) da parte aérea e total com os teores de P na parte aérea e índices de eficiência de utilização de P(IE), classificando os cultivares estudados em eficientes e responsivos, eficientes não responsivos, ineficientes responsivos e ineficientes e não responsivos, concluindo-se que os cultivares eficientes e responsivos mostraram os maiores valores para MS de parte aérea, total e IE, e os menores teores de P na parte aérea. 


\section{MATERIAL E MÉTODOS}

\subsection{Aspectos gerais}

\subsubsection{Local}

Dois experimentos foram conduzidos, concomitantemente, em condição de casa de vegetação, no Centro de Energia Nuclear na Agricultura, Campus Luiz de Queiroz, Universidade de São Paulo (CENA/USP).

\subsubsection{Espécies vegetais}

Foram utilizados 32 cultivares de soja [Glycine max (L.) Merr.] cujas sementes foram inoculadas com Bradyrhizobium japonicum SEMIA 587 e 5019. Foi aplicado 1 $\mathrm{mL} / \mathrm{semente}$ do inoculante na semeadura. Como plantas controle foram cultivados: feijão guandu (Cajanus cajan L.), cultivar IAC Fava Larga e arroz (Oryza sativa L), cultivar IAC 165, plantas reconhecidas como eficientes na absorção de fósforo (Hocking et al. 1997; Fernandes, 2001). Os cultivares de soja escolhidos foram àqueles mais utilizados nas áreas produtoras principalmente das áreas do cerrado brasileiro e estão apresentados na Tabela 1. 
Tabela 1. Características dos cultivares de soja [Glycine $\max$ (L.) Merr.] utilizados.

\begin{tabular}{|c|c|c|c|}
\hline Cultivar & Ciclo & Crescimento & Altura \\
\hline M-Soy 6101 & Precoce & Indeterminado & $105-120$ \\
\hline M-Soy 8001 & Precoce & Determinado & 75 \\
\hline DM 118 & Precoce & Determinado & 86 \\
\hline IAC-22 & Precoce & Determinado & $60-70$ \\
\hline IAC-23 & Precoce & Determinado & 67 \\
\hline EMGOPA 316 & Precoce & Determinado & 70 \\
\hline M-Soy 8400 & Semiprecoce & Determinado & 75 \\
\hline M-Soy 8411 & Semiprecoce & Determinado & 90 \\
\hline IAC- 18 & Semiprecoce & Determinado & $70-90$ \\
\hline IAC-24 & Semiprecoce & Determinado & 72 \\
\hline DM 247 & Semiprecoce & Determinado & 87 \\
\hline BRS 133 & Semiprecoce & Determinado & 70 \\
\hline BRS Carla & Semiprecoce & Determinado & 75 \\
\hline DM 339 & Semitardio & Determinado & 86 \\
\hline DM Vitória & Semitardio & Determinado & 80 \\
\hline IAC-19 & Semitardio & Determinado & $80-100$ \\
\hline IAC PL-1 & Semitardio & Determinado & 80 \\
\hline M-Soy 9350 & Semitardio & Determinado & $90-120$ \\
\hline BRS Milena & Semitardio & Determinado & 100 \\
\hline BRAS 98-5409 & Semitardio & Determinado & 90 \\
\hline MG/BR 46 Conquista & Semitardio & Determinado & 90 \\
\hline BRSGO Bela Vista & Semitardio & Determinado & 85 \\
\hline M-Soy 8866 & Semitardio & Determinado & 90 \\
\hline $98 \mathrm{C} 81$ & Semitardio & Determinado & 92 \\
\hline M-Soy 9001 & Tardio & Determinado & 90 \\
\hline DM Nobre & Tardio & Determinado & 96 \\
\hline DM 309 & Tardio & Determinado & 86 \\
\hline BRSGO Jataí & Tardio & Determinado & 90 \\
\hline BRAS 9530080 & Tardio & Determinado & 100 \\
\hline BRAS $97-1368$ & Tardio & Determinado & 95 \\
\hline BRS Celeste & Tardio & Determinado & 100 \\
\hline BRAS $97-7371$ & Tardio & Determinado & $95-$ \\
\hline
\end{tabular}




\subsubsection{Solo}

Utilizou-se LATOSSOLO VERMELHO-AMARELO Distrófico de textura argilosa, cultivado anteriormente com milho e soja, oriundo do município de Planaltina de Goiás - GO, região do Cerrado central brasileiro. A coleta de terra foi feita na profundidade de $0-20 \mathrm{~cm}$, formando-se uma amostra composta, homogeneizada, seca ao ar e passada em peneira com malha de dois $\mathrm{mm}$ de abertura. As caracterizações químicas e físicas foram determinadas em laboratório segundo os métodos descritos por Raij \& Quaggio (1983) e Camargo et al. (1986), respectivamente e estão contidas na Tabela 2.

Tabela 2. Características químicas e físicas do Latossolo Vermelho Amarelo Distrófico coletado na camada de 0 a $20 \mathrm{~cm}$ de profundidade.

\begin{tabular}{|c|c|}
\hline \multicolumn{2}{|c|}{ Solo - LVA } \\
\hline Características & Latossolo Vermelho Amarelo Distrófico ${ }^{(1)}$ \\
\hline $\mathrm{pH}\left(\mathrm{CaCl}_{2}\right)$ & 5,50 \\
\hline Matéria orgânica $\left(\mathrm{g} \mathrm{dm}^{-3}\right)$ & 18,32 \\
\hline$P\left(\mathrm{mg} \mathrm{dm}^{-3}\right)$ & 20,32 \\
\hline $\mathrm{K}\left(\mathrm{mmol}_{\mathrm{c}} \mathrm{dm} \mathrm{m}^{-3}\right)$ & 2,42 \\
\hline $\mathrm{Ca}\left(\mathrm{mmol}_{\mathrm{c}} \mathrm{dm}^{-3}\right)$ & 32,48 \\
\hline $\operatorname{Mg}\left(\mathrm{mmol}_{\mathrm{c}} \mathrm{dm} \mathrm{m}^{-3}\right)$ & 13,99 \\
\hline $\mathrm{H}+\mathrm{Al}\left(\mathrm{mmol}_{\mathrm{c}} \mathbf{d m}^{-3}\right)$ & 24,98 \\
\hline $\mathrm{SB}\left(\mathrm{mmol}_{\mathrm{c}} \mathrm{dm}^{-3}\right)$ & 48,89 \\
\hline $\mathrm{T}\left(\mathrm{mmol}_{\mathrm{c}} \mathrm{dm}^{-3}\right)$ & 73,78 \\
\hline$V(\%)$ & 66,3 \\
\hline $\mathrm{Fe}\left(\mathrm{mg} \mathrm{dm}^{-3}\right)$ & 21,90 \\
\hline $\operatorname{Mn}\left(\mathbf{m g ~ d m} \mathbf{m}^{-3}\right)$ & 3,20 \\
\hline $\mathrm{Cu}\left(\mathrm{mg} \mathrm{dm} \mathbf{m}^{-3}\right)$ & 1,42 \\
\hline $\mathrm{Zn}\left(\mathrm{mg} \mathrm{dm} \mathbf{m}^{-3}\right)$ & 0,59 \\
\hline Areia (\%) & 29,6 \\
\hline Silte $(\%)$ & 30,4 \\
\hline Argila (\%) & 40,0 \\
\hline
\end{tabular}

(1) Classificação Brasileira, EMBRAPA (1999). Método IAC (1983) 


\subsection{Experimento 1: Avaliação bioquímica das plantas: Fosfatase Ácida}

\subsubsection{Condução do experimento}

Colocou-se $0,2 \mathrm{~kg}$ de material de solo já descrito anteriormente em copos plásticos com diâmetro superior e inferior medindo respectivamente 6,8 e 4,3 cm e altura $9,3 \mathrm{~cm}$ e foram colocadas para germinar quatro sementes por vaso. A emergência das plântulas ocorreu três dias após a semeadura (DAS) e sete dias após a emergência (DAE) o desbaste foi realizado, no estágio $\mathrm{V}_{1}$ (primeiro trifólio), deixando-se uma planta por vaso. Aplicou-se o correspondente a $0,05 \mathrm{mmol}_{\mathrm{c}} \mathrm{dm}^{-3} \mathrm{de} \mathrm{K}$ por copo, na forma de cloreto de potássio, quinze dias após a emergência.

\subsubsection{Determinação da atividade da fosfatase ácida}

Decorridos 46 DAE, realizou-se a avaliação da atividade da enzima fosfatase ácida (E.C.3.1.3.2) no terceiro e quarto trifólios, "in vivo", segundo método descrito por Besford, (1979c), com algumas modificações em função da espécie estudada.

Utilizou-se $100 \mathrm{mg}$ de fragmentos de $2 \mathrm{~mm}$ de diâmetro de limbo foliar, de material fresco, recém-coletado, correspondendo ao terceiro trifólio das plantas contidas no vaso (Ambrosano et al., 1996). Os fragmentos foliares foram incubados com $8 \mathrm{~mL}$ de paranitrofenilfosfato (p-NFP) $0,25 \mathrm{mmol} \mathrm{L}^{-1}$ em tampão acetato de sódio $0,1 \mathrm{~mol} \mathrm{~L}^{-1}$ (pH 4,0). Após incubação por 20 minutos, no escuro, em banho-maria a $30^{\circ} \mathrm{C}, 5 \mathrm{~mL}$ da mistura da reação foram alcalinizadas com $2 \mathrm{~mL}$ de $\mathrm{NaOH} 2 \mathrm{~mol} \mathrm{~L}{ }^{-1}$. A leitura foi feita medindo-se a densidade ótica em fotocolorímetro Klett-Summerson equipado com filtro azul ( $\left.\mathrm{n}^{\circ} 42\right)$, estimando-se a quantidade de paranitrofenol (p-NFOH) formado, contra um branco que continha todos os reagentes exceto os fragmentos foliares. As análises da concentração de $\mathrm{P}$ foram executadas no restante das mesmas folhas (sem o pecíolo), utilizadas para a avaliação da enzima fosfatase ácida. O substrato tamponado paranitrofenilfosfato (p-NFP) é hidrolisado pela fosfatase ácida resultando em para- 
nitrofenol (p-NFOH). Através de uma curva padrão, quantifica-se o p-NFP hidrolisado determinando-se a atividade enzimática que foi expressa em $\mu$ moles de substrato hidrolisado (p-NFP) por hora, por grama de tecido foliar fresco $\left(\mu \mathrm{mol} \mathrm{h}^{-1} \mathrm{~g}^{-1}\right)$.

Os diferentes cultivares foram avaliados em termos de atividade da fosfatase ácida, concentração de fósforo na folha diagnóstico e biomassa da parte aérea.

\subsubsection{Análise estatística}

O delineamento experimental utilizado foi em blocos completos ao acaso, com três repetições, totalizando 102 vasos. Os resultados das variáveis obtidas foram submetidos às análises estatísticas utilizando-se o programa estatístico SAS - System for Windows 6,11 (SAS Inc. 1996), através do procedimento GLM. Realizou-se a análise de variância, e, em função do nível de significância no teste $\mathrm{F}$, efetuou-se a comparação das médias pelo teste de Tukey $(P<0,05)$. Avaliação de correlação entre a atividade da fosfatase ácida, biomassa da parte aérea e concentração de $\mathrm{P}$ na folha foi realizada utilizando o SAS, através do procedimento CORR, calculando-se o coeficiente de correlação de Pearson.

\subsection{Experimento 2: Eficiência de absorção e utilização de $P$ em cultivares de soja}

\subsubsection{Instalação e condução do experimento}

Foram colocados $1,8 \mathrm{~kg}$ de solo em vasos plásticos revestidos internamente com saco plástico grosso objetivando evitar vazamentos de água e terra. Preparou-se 102 copinhos descartáveis com $20 \mathrm{~g}$ de areia fina que receberam $5 \mathrm{MBq}$ (megabecquerel) de ${ }^{32} \mathrm{P}$ livre de carregador na forma de $\mathrm{KH}_{2} \mathrm{PO}_{4}$. Após 24 horas, a areia foi homogeneizada e cada copinho foi aplicado no saco com o solo marcando-o uniformemente mediante uma agitação vigorosa. 
Procedeu-se a semeadura referente aos 34 tratamentos previstos, cada um com três repetições, totalizando 102 parcelas experimentais. Cada vaso recebeu seis sementes inoculadas com estirpes de rizóbio. A umidade do solo foi monitorada mantendo a $60 \%$ da capacidade de campo, que foi semanalmente determinada através da diferença das pesagens dos vasos.

A emergência das plântulas ocorreu quatro dias após e o desbaste foi realizado, no estágio $V_{1}$ (primeiro trifólio), deixando-se duas plantas por vaso. Aplicou-se a 0,05 $\mathrm{mmol}_{\mathrm{c}} \mathrm{dm}^{-3}$ de $\mathrm{K}$ por vaso, na forma de cloreto de potássio, quinze dias após a emergência.

\subsubsection{Coleta do material vegetal e produção de matéria seca}

A colheita das plantas foi feita $45 \mathrm{DAE}$, cortando-se a parte aérea rente ao solo. O sistema radicular foi retirado do vaso e lavado em peneira de forma a evitar a perda da raiz, seguido do seu acondicionamento em sacos de papel. Ambos foram secos em estufa com circulação forçada de ar a $65^{\circ} \mathrm{C}$ por 72 horas, para posterior determinação da massa da parte aérea e raiz. A seguir o material vegetal foi moído em moinho tipo Willey, provido de peneira de 20 meshes.

\subsubsection{Colonização das raízes pelos fungos micorrízicos arbusculares (FMAs)}

As raízes mais finas foram recolhidas e colocadas em solução de FAA (Ácido Fórmico + Ácido Acético + Água destilada) para conservação. Para a coloração da raiz procedeu-se segundo técnica descrita por Phillips \& Hayman (1970). Na determinação da porcentagem de colonização pelos fungos micorrízicos arbusculares, seguiu-se metodologia de Giovannetti \& Mosse (1980). Após a determinação, essas raízes foram lavadas, secas em estufa com circulação forçada de ar a $65^{\circ} \mathrm{C}$ por 72 horas, pesadas junto com a raiz remanescente obtendo-se o peso da matéria seca total de raiz. 


\subsubsection{Avaliação da eficiência de absorção de $P$}

Os indicadores utilizados para a avaliação da eficiência de absorção de fósforo, foram os seguintes:

\subsubsection{Concentração, conteúdo de fósforo e contagem de ${ }^{32} \mathrm{P}$}

A determinação da concentração de fósforo contido na parte aérea e raízes foi efetuada conforme metodologia descrita por Sarruge \& Haag (1974).

$\mathrm{O}$ fósforo total foi extraído por digestão ácida à quente com $\mathrm{HNO}_{3}$ e $\mathrm{HClO}_{4}$ (digestão nitroperclórica), e determinado por colorimetria do metavanadato e a contagem do ${ }^{32} \mathrm{P}(\mathrm{CPM})$ por efeito Cerenkov em contador por cintilação líquida.

\subsubsection{Cálculo da atividade específica (S)}

A técnica da diluição isotópica de ${ }^{32} \mathrm{P}$ foi utilizada neste trabalho para a avaliação dos cultivares de soja quanto à eficiência na absorção de $\mathrm{P}$ de solos de cerrado, calculando-se a atividade específica (S).

Com os valores da concentração de $\mathrm{P}$ e da contagem de ${ }^{32} \mathrm{P}$, foi calculada a atividade específica (S) da parte aérea e raiz, para a avaliação da eficiência na absorção do $\mathrm{P}$ do solo. Quanto menor a atividade específica, maior a eficiência na absorção de $\mathrm{P}$ do solo (Hocking et al., 1997).

A atividade específica foi calculada pela fórmula:

$$
\mathbf{S}=\mathbf{A t} \cdot{ }^{32} \mathbf{P} / \mathbf{P}
$$

Sendo: $\mathrm{S}=$ atividade específica em $\mathrm{CPM} \mu \mathrm{g}^{-1} ; \mathrm{At}^{32} \mathrm{P}=$ Atividade do ${ }^{32} \mathrm{P}$ em contagens por minuto (CPM); $\mathrm{P}=$ quantidade de $\mathrm{P}$ acumulado na parte aérea ou na raiz, em microgramas $(\mu \mathrm{g})$. 


\subsubsection{Cálculo de razão de eficiência radicular (RER)}

Este indicador corresponde à razão entre o conteúdo de $\mathrm{P}$ da parte aérea e a biomassa radicular (Jones et al., 1989) e descreve a habilidade da planta em obter P do solo, e é dado pela fórmula:

\section{$\operatorname{RER}_{\mathbf{P}}=\mathbf{P} / \mathbf{B}$}

Onde: $\mathbf{R E R}_{\mathbf{P}}=$ razão de eficiência radicular de $\mathrm{P}$, em $\mathrm{mg} \mathrm{g}^{-1} ; \mathbf{P}=$ conteúdo total de $\mathrm{P}$ na parte aérea da planta em miligramas $(\mathrm{mg}) ; \mathbf{B}=$ biomassa radicular em gramas $(\mathrm{g})$.

\subsubsection{Avaliação da eficiência de utilização de $P$}

O indicador empregado na avaliação da eficiência de utilização de $\mathrm{P}$, foi o índice de utilização de P (IUP). Para se determinar a eficiência de utilização do fósforo, utilizou-se o método proposto por Siddiqi \& Glass (1981). Esses autores propuseram que a eficiência ou índice de utilização (IUP), seria mais válido se expresso pelo produto do quociente de utilização (Q) pela biomassa produzida (W). O quociente de utilização (Q) é a razão entre a biomassa (W) e a quantidade total de nutriente, que neste experimento foi simbolizado por $\mathrm{P}$, contido na biomassa, sendo dado pela fórmula abaixo:

$$
\text { IUP }=W^{2} / P\left(g^{2} \mathrm{mg}^{-1} \text { de P }\right)
$$

Onde: $\mathbf{W}=$ produção de biomassa, em gramas $(\mathrm{g}) ; \mathbf{P}=$ conteúdo total de $\mathrm{P}$ na planta (mg). 


\subsubsection{Análise estatística}

O delineamento experimental foi inteiramente casualizado, com 3 repetições, totalizando 102 vasos. Os resultados das variáveis obtidas foram submetidos às análises estatísticas utilizando-se o aplicativo estatístico SAS - System for Windows 6,11 (SAS Inc. 1996), através do procedimento GLM. Realizou-se a análise de variância, e em função do nível de significância no teste $\mathrm{F}$, efetuou-se a comparação das médias pelo teste de Tukey $(P<0,05)$. Avaliação de correlação entre as variáveis estudadas, inclusive com a atividade da fosfatase ácida e atividade específica foi realizada utilizando o SAS, através do procedimento CORR, calculando-se o coeficiente de correlação de Pearson. 


\section{RESULTADOS E DISCUSSÃO}

\subsection{Experimento 1: Avaliação bioquímica das plantas: Fosfatase Ácida}

Ocorreram diferenças $(P<0,05)$ para a atividade da fosfatase ácida, concentração de $\mathrm{P}$ na folha diagnóstico e biomassa da parte aérea entre os cultivares de soja, o feijão guandu e o arroz (Tabelas 3, 4 e 5). Estes fatos demonstram que sob a mesma condição de fertilidade do solo cultivares de soja, guandu e o arroz apresentam comportamentos diferentes quanto à eficiência de aquisição e utilização de fósforo.

O cultivar IAC-19 embora tenha apresentado maior valor da atividade enzimática não diferiu dos cultivares BRS Milena, BRAS 97-7371, DM-247, DM-118, BRS Celeste, IAC-18, BRS Carla, DM-Vitória, MG/BR 46 Conquista, IAC-24, BRSGO Bela Vista e M-Soy 8866, além do feijão guandu, que apresentaram atividade da fosfatase ácida semelhantes. Os cultivares M-Soy 9350 e IAC-23 não diferiram dos cultivares citados anteriormente menos IAC-19. As menores atividades enzimáticas foram dos cultivares M-Soy 6101, M-Soy 8001 e arroz, sendo que M-Soy 6101 não diferiu de BRSGO Jataí, M-Soy 9001 e EMGOPA 316.

A utilização da atividade da fosfatase ácida tem sido sugerida como indicador bioquímico da deficiência de P nas culturas (Besford,1979a,b). A enzima fosfatase ácida atua hidrolizando $\mathrm{P}$ de compostos orgânicos dos tecidos mais velhos translocando para os mais novos. Esta atividade é ampliada tanto nas raízes como nas folhas quando ocorre um estado de deficiência ou estresse de P na planta (Furlani \& Machado, 2002). Não são conhecidas na literatura informações sobre valores da atividade enzimática para os cultivares de soja em solos com baixa disponibilidade de P e esta informação auxiliaria 
na avaliação do estado nutricional da cultura da soja através da avaliação da atividade da fosfatase ácida em folhas ou raízes de plantas.

Tabela 3. Atividade da fosfatase ácida de trinta e dois cultivares de soja, acompanhados por dois controles, arroz e feijão guandu cultivados em solo LVA distrófico do cerrado. (média de 3 repetições).

\begin{tabular}{|c|c|}
\hline \multirow{2}{*}{ Cultivar } & Atividade Fosfatase Ácida \\
\hline & $\ldots \ldots \ldots \ldots \ldots \mathrm{mol} \mathrm{h}^{-1} \mathrm{~g}^{-1} \ldots \ldots \ldots \ldots \ldots$ \\
\hline IAC-19 & $12,74 \mathrm{a}$ \\
\hline BRS Milena & $12,36 \mathrm{ab}$ \\
\hline BRAS $97-7371$ & $12,08 \mathrm{abc}$ \\
\hline DM 247 & $11,80 \mathrm{abcd}$ \\
\hline DM 118 & 11,69 abcd \\
\hline BRS Celeste & 11,12 abcde \\
\hline IAC- 18 & 11,08 abcdef \\
\hline BRS Carla & 11,08 abcdef \\
\hline DM Vitória & 11,06 abcdef \\
\hline MG/BR 46 Conquista & 11,03 abcdefg \\
\hline IAC-24 & 10,77 abcdefg \\
\hline BRSGO Bela Vista & 10,71 abcdefg \\
\hline M-Soy 8866 & 10,51 abcdefgh \\
\hline M-Soy 9350 & 10,38 bcdefgh \\
\hline IAC-23 & 10,29 bcdefgh \\
\hline IAC 22 & 9,91 cdefgh \\
\hline BRS 133 & defghij \\
\hline DM 339 & efghijk \\
\hline IAC PL-1 & efghijk \\
\hline $98 C 81$ & efghijk \\
\hline M-Soy 8411 & efghijk \\
\hline DM 309 & efghijk \\
\hline BRAS 98-5409 & fghijk \\
\hline DM Nobre & fghijk \\
\hline M-Soy 8400 & ghijk \\
\hline BRAS 97-1368 & hijk \\
\hline BRSGO-Jataí & 7,91 \\
\hline M-Soy 9001 & 7,54 \\
\hline EMGOPA 316 & 7,44 \\
\hline BRAS 95-30080 & 7,26 \\
\hline M-Soy 6101 & 5,86 \\
\hline M-Soy 8001 & 4,13 \\
\hline F. GUANDU & 10,71 abcdefg \\
\hline Arroz & 2,31 \\
\hline C.V. $(\%)$ & 7,43 \\
\hline D.M.S. & 2,288 \\
\hline D.P.M. & 0,0695 \\
\hline
\end{tabular}

Médias seguidas pelas mesmas letras não diferem entre si pelo teste de Tukey ao nível de $5 \%$. 
Diversos trabalhos relatam estudos com de doses de $\mathrm{P}$ em solo ou em solução nutritiva em culturas, estabelecendo correlações sem uma definição de padrões que viessem a auxiliar na diagnose. Neste estudo trabalhou-se com solo no mesmo nivel de fertilidade e avaliou-se a atividade da fosfatase ácida dos cultivares de soja, do arroz e do feijão guandu. Em média, o maior valor atingiu $12,74 \mu \mathrm{mol}$ p-NPP h ${ }^{-1} \mathrm{~g}^{-1}$ e o menor valor 4,13 $\mu \mathrm{mol} \mathrm{p-NPP} \mathrm{h}^{-1} \mathrm{~g}^{-1}$, para os cultivares de soja. No caso do feijão guandu o valor da fosfatase ácida esteve entre os maiores valores e no caso do arroz obteve-se a menor atividade da fosfatase ácida (Tabela 3). A maior capacidade de exploração do solo pelo sistema radicular presente no arroz provavelmente promove maior eficiência à aquisição de $\mathrm{P}$ em relação aos cultivares de soja e guandu o que evidencia uma menor atividade da fosfatase em condição de estresse de $\mathrm{P}$, possibilitando melhor estado nutricional do arroz (Tabela 5) e maior capacidade de adaptação.

O feijão guandu é reconhecido pela sua capacidade de secreção de ácidos piscídico (Otani et al., 1996) e contribui para a mobilização de nutrientes notadamente $\mathrm{P}$, elemento essencial para o seu desenvolvimento e para o processo de fixação biológica de nitrogênio, gerando alto valor de atividade enzimática, como ocorreu neste estudo (Tabela 3), propiciando uma concentração de $\mathrm{P}$ superior a muitos cultivares de soja avaliados (Tabela 5).

A cultura da soja é tida como uma planta não secretora ou pouco secretora de ácidos orgânicos (Hocking \& Randall, 2001), e apresenta uma dependência de agentes que auxiliem na mobilização de $\mathrm{P}$ para o seu desenvolvimento em ambientes pobres em fósforo. A ocorrência de diferenças entre os valores determinados para a atividade da fosfatase ácida em cultivares de soja nem sempre evidencia a presença de cultivares mais eficientes na aquisição e utilização de $P$.

Estudos com marcadores genéticos, em genótipos de feijoeiro, um eficiente e outro ineficiente, verificou-se que o locus do gene da fosfatase ácida não estava associado aos loci que conferem a eficiência na aquisição ou na utilização de P (Furlani \& Machado, 2002). 
Tabela 4. Biomassa da parte aérea de trinta e dois cultivares de soja, acompanhados por dois cultivares controle, arroz e feijão guandu cultivado em solo LVA distrófico do cerrado. (média de 3 repetições).

\begin{tabular}{|c|c|}
\hline \multirow{2}{*}{ Cultivar } & Biomassa parte aérea \\
\hline & ...................... p planta ${ }^{-1} \ldots \ldots \ldots \ldots \ldots \ldots$ \\
\hline BRAS 97-7371 & $2,59 \mathrm{a}$ \\
\hline IAC PL-1 & $2,51 \mathrm{ab}$ \\
\hline DM-118 & $2,32 \mathrm{abc}$ \\
\hline DM-Vitória & $2,30 \mathrm{abc}$ \\
\hline DM-247 & $2,30 \mathrm{abc}$ \\
\hline BRS Milena & $2,21 \mathrm{abcd}$ \\
\hline 1AC-23 & $2,20 \mathrm{abcd}$ \\
\hline M-Soy 8001 & $2,12 \mathrm{abcd}$ \\
\hline BRS Celeste & 2,11abcde \\
\hline BRAS 95-30080 & 2,10abcde \\
\hline M-Soy 9001 & $2,07 \mathrm{abcdef}$ \\
\hline MG/BR 46 Conquista & $2,05 \mathrm{abcdef}$ \\
\hline BRAS 97-1368 & 2,05abcdef \\
\hline IAC-24 & $2,04 \mathrm{abcdef}$ \\
\hline IAC-19 & $2,02 \mathrm{abcdef}$ \\
\hline M-Soy 8400 & 2,00 bcdefg \\
\hline M-Soy 6101 & 1,99 bcdefg \\
\hline BRS Carla & 1,98 bcdefg \\
\hline DM-339 & 1,96 bcdefg \\
\hline M-Soy 9350 & 1,90 cdefg \\
\hline DM-Nobre & 1,89 cdefg \\
\hline BRAS 98-5409 & 1,84 cdefg \\
\hline $98 \mathrm{C} 81$ & 1,83 cdefg \\
\hline BRS 133 & 1,83 cdefg \\
\hline BRSGO Bela Vista & 1,81 cdefg \\
\hline IAC-22 & 1,79 cdefg \\
\hline M-Soy 8866 & 1,79 cdefg \\
\hline IAC-18 & 1,79 cdefg \\
\hline M-Soy 8411 & $1,70 \quad$ defg \\
\hline DM 309 & 1,54 \\
\hline EMGOPA 316 & 1,51 \\
\hline BRSGO Jataí & 1,43 \\
\hline Arroz & 0,93 \\
\hline F. Guandu & 0,61 \\
\hline C.V. $(\%)$ & 9,20 \\
\hline D.M.S. & 0,573 \\
\hline D.P.M. & 0,017 \\
\hline
\end{tabular}

Médias seguidas pelas mesmas letras não diferem entre si pelo teste de Tukey ao nível de $5 \%$. 
A alta atividade enzimática pode ser um sinal de estresse da planta que necessita de maior quantidade de $\mathrm{P}$ externo para o seu desenvolvimento. Por outro lado, a presença de cultivares como M-Soy 8001 que apresentou atividade da fosfatase ácida correspondente a um terço do valor de cultivares que alcançaram maiores atividades da enzima, IAC-19 por exemplo, ligado ao fato de não haver diferença $(P<0,05)$ na produção de biomassa na parte aérea e concentração de $\mathrm{P}$, evidencia a existência de cultivares que possuem mecanismos que promovem maior eficiência de aquisição e utilização de P.

Com relação à biomassa da parte aérea os cultivares BRAS 97-7371, IAC PL-1, DM-118, DM-Vitória, DM-247, BRS Milena, IAC-23, M-SOY 8001, BRS Celeste, BRAS 95-30080, M-SOY 9001, MG/BR Conquista, BRAS 97-1368, IAC-24 e IAC-19 não diferiram entre si $(P<0,05)$ sendo que BRAS 97-7371 diferiu dos demais cultivares apresentando maior biomassa da parte aérea. Os menores valores de biomassa da parte aérea foram do arroz e do guandu que não diferiram entre si $(P<0,05)$.

O arroz, juntamente com os cultivares IAC-18, DM-309, BRSGO Jataí, MG/BR 46 Conquista, IAC-24, BRAS 98-5409, IAC-19, M-Soy 8866, EMGOPA 316, M-Soy 6101, M-Soy 9350, M-Soy 8400, BRS 133, BRS Milena, Guandu, BRS Celeste, DM247 e BRSGO Bela Vista, não diferiram $(P<0,05)$ com relação à concentração de $\mathrm{P}$ na folha diagnóstica, obtendo valores entre $1,58 \mathrm{~g} \mathrm{~kg}^{-1}$ e $1,27 \mathrm{~g} \mathrm{~kg}^{-1}$. Os cultivares que apresentaram a menor concentração de $\mathrm{P}$ apresentaram maior biomassa da parte aérea (Tabelas 4 e 5 ).

\section{Correlações entre as variáveis}

Foram determinados os coeficientes de correlações entre a atividade da fosfatase ácida, biomassa da parte aérea e concentração de $\mathrm{P}$ na folha diagnóstico (Tabela 6). Constatouse que a atividade da fosfatase ácida correlacionou-se positivamente $(P<0,0 l)$ com a biomassa da parte aérea. Estes resultados demonstram que nos cultivares que apresentaram maior biomassa da parte aérea a atividade da fosfatase ácida também foi elevada. Correlações negativas entre a atividade da fosfatase ácida e a produção de 
Tabela 5. Concentração de fósforo na folha diagnóstico (PFd) de trinta e dois cultivares de soja, acompanhados por dois cultivares controle, arroz e feijão guandu cultivados em vaso utilizando solo LVA distrófico do cerrado. (média de 3 repetições).

\begin{tabular}{|c|c|}
\hline \multirow{2}{*}{ Cultivar } & $\mathbf{P}$ \\
\hline & 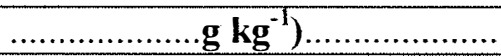 \\
\hline IAC-18 & $1,51 \mathrm{ab}$ \\
\hline DM-309 & $1,50 \mathrm{abc}$ \\
\hline BRSGO Jataí & 1,49abc \\
\hline MG/BR 46 Conquista & $1,43 \mathrm{abcd}$ \\
\hline IAC-24 & $1,43 \mathrm{abcd}$ \\
\hline BRAS 98-5409 & $1,42 \mathrm{abcd}$ \\
\hline IAC-19 & $1,42 \mathrm{abcd}$ \\
\hline M-Soy 8866 & 1,37abcde \\
\hline EMGOPA 316 & 1,36abcde \\
\hline M-Soy 6101 & 1,36abcde \\
\hline M-Soy 9350 & $1,35 \mathrm{abcde}$ \\
\hline M-Soy 8400 & $1,34 \mathrm{abcde}$ \\
\hline BRS 133 & 1,33abcde \\
\hline BRS Milena & 1,32abcde \\
\hline BRS Celeste & 1,29abcdef \\
\hline DM-247 & 1,27abcdef \\
\hline BRSGO Bela Vista & $1,27 \mathrm{abcdef}$ \\
\hline $98 \mathrm{C} 81$ & 1,26 bcdef \\
\hline IAC 23 & 1,26 bcdef \\
\hline DM-339 & 1,25 bcdef \\
\hline IAC 22 & 1,24 bcdef \\
\hline BRAS 95-30080 & 1,24 bcdef \\
\hline DM-118 & 1,23 bcdef \\
\hline BRAS 97-1368 & 1,21 bcdef \\
\hline BRS Carla & 1,21 bcdef \\
\hline M-Soy 9001 & 1,20 bcdef \\
\hline M-Soy 8001 & 1,20 bcdef \\
\hline DM Vitória & 1,19 cdef \\
\hline M-Soy 8411 & 1,17 def \\
\hline DM-Nobre & 1,10 \\
\hline IAC PL-1 & 1,06 \\
\hline BRAS $97-7371$ & $0,98 \quad \mathrm{f}$ \\
\hline F.GUANDU & $1,32 \mathrm{abcde}$ \\
\hline Arroz & $1,58 \mathrm{a}$ \\
\hline C.V. $(\%)$ & 7,45 \\
\hline D.M.S. & 2,29 \\
\hline D.P.M. & 0,00957 \\
\hline
\end{tabular}

Médias seguidas pelas mesmas letras não diferem entre si pelo teste de Tukey ao nível de $5 \%$. 
matéria seca é mencionada por Furlani \& Machado (2002), contudo, o que acontece com a relação entre a atividade da fosfatase ácido e a biomassa da parte aérea entre os cultivares estudados, dentro da mesma concentração de $\mathrm{P}$ disponível do solo, não é relatado na literatura.

Embora o coeficiente de correlação entre a atividade da fosfatase ácida e a concentração de $\mathrm{P}$ tenha sido negativo, não foi significativo $(P=0,1356)$. Numerosas referências têm indicado a relação negativa existente entre a atividade da fosfatase ácida em doses de $\mathrm{P}$ no solo e os teores de fósforo nos tecidos de espécies vegetais como: Licopersicon esculentum Mill (Hewitt \& Tathan, 1960; Besford, 1979a,b), Oryza sativa L (Zaini \& Mercado, 1985), Saccharum officinarum L (Silva \& Basso, 1993), Triticum aestivum L (McLachlan, 1982; McLachlan et al., 1987), Phaseolus vulgaris L e Vigna unguiculata L Walp (Fernandez \& Ascencio, 1994; Ascencio, 1994), Cajanus cajan L e Gossypium hirsutum L (Ascencio, 1994), Cucumis sativus L (Besford, 1978) e Bactris gasipaes Kunth (Bovi et al., 1998).

A biomassa da parte aérea correlacionou-se significativamente $(P<0,01)$ obtendo-se coeficiente positivo com a concentração de $\mathrm{P}$ na folha diagnóstica. Isto indica claramente que à medida que a planta aumenta sua biomassa da parte aérea diminui a concentração de $\mathrm{P}$ na folha diagnóstica, caracterizando o efeito de diluição do nutriente nos tecidos (Jarrel \& Beverly, 1981).

Tabela 6. Estimativas dos coeficientes de correlação simples entre as variáveis estudadas em trinta e dois cultivares de soja e respectivos controles, cultivados em LVA distrófico do cerrado. Tamanho da amostra $=102$.

\begin{tabular}{lccc}
\hline \multicolumn{1}{c}{ Variável } & Fosfatase ácida & Biomassa P. Aérea & PFd \\
\hline Fosfatase ácida & - & $0,345^{*}$ & $-0,149 \mathrm{~ns}$ \\
Biomassa P. Aérea & - & - & $-0,485^{* *}$ \\
PFd & - & - & - \\
\hline
\end{tabular}

Para que os cultivares aumentem a produção de biomassa da parte aérea torna-se indispensável à alocação de $\mathrm{P}$ em seus tecidos a níveis adequados. A translocação de $\mathrm{P}$ 
das raízes para a parte aérea é diminuída em estágios avançados de deficiência, retendose mais P em suas raizes (Cogliatti \& Clarkson, 1983). As plantas em desenvolvimento e estressadas por falta de $\mathrm{P}$ "aceleram" a atividade da fosfatase ácida para garantir o suprimento de $\mathrm{P}$ pela liberação do Po para $\mathrm{P}$ inorgânico dos tecidos mais velhos, e rápida remobilização para as partes em crescimento. Alguns cultivares de soja parecem mais bem adaptados em ambientes com baixa disponibilidade de $\mathrm{P}$ no solo que outros e por isso apresentam maior produção de biomassa de parte aérea, menor atividade da fosfatase ácida, mesmo com uma menor concentração de $\mathrm{P}$ em seus tecidos e, neste caso, discute-se a hipótese da existência de cultivares de soja sejam mais adaptados a ambientes edáficos pobres em $\mathrm{P}$ disponível e eficientes na aquisição e utilização de $\mathrm{P}$.

\subsection{Experimento 2: Eficiência de absorção e utilização de $P$ em cultivares de soja, do feijão guandu e do arroz}

\subsubsection{Produção de biomassa da parte aérea e raiz}

Ocorreu diferenciação de produção de biomassa da parte aérea, raiz, relação parte aérea / raiz e biomassa total $(P<0,05)$ entre os cultivares de soja, guandu e arroz (Tabelas 7, 8, 9 e 10).

$\mathrm{Na}$ produção de biomassa da parte aérea não houve predominância de um determinado ciclo sobre o outro durante o período estudado ocorrendo cultivares precoces, semiprecoces, semitardios e tardios que apresentaram maior e menor desempenhos, merecendo destaque os cultivares IAC PL-1 e BRAS 97-7371 que apresentaram maiores valores de biomassa, não diferindo dos cultivares DM-118, DM247 e DM-Vitória, sendo superiores aos demais cultivares. Os valores de biomassa da parte aérea entre os cultivares de soja variaram de 2,91 a 1,77 $\mathrm{g} \mathrm{planta}^{-1}$ (Tabela 7).

Quanto às produções de biomassas das raízes dos cultivares de soja os valores variaram de 1,09 a $0,51 \mathrm{~g} \mathrm{planta}^{-1}$ (Tabela 8). Os cultivares BRSGO Jataí e BRAS 98-5409 apresentaram menor biomassa da raiz em relação aos cultivares M-Soy 8001, M-Soy 8866, BRS Milena, BRAS 97-7371, M-Soy 8400, BRAS 95-30080 e 
BRAS 97-1368. As gramíneas geralmente não apresentam influxo de $\mathrm{P}$ maior que as leguminosas, no entanto, são consideradas mais competitivas no crescimento sob baixa disponibilidade de P (Araújo, 2000). No entanto, os resultados demonstram que nem sempre este fato constitui uma regra uma vez que os cultivares de soja M-Soy 8001 e MSoy 8866 apresentaram maior biomassa de raiz que o arroz (Tabela 8).

A relação parte aérea:raiz, é uma variável que vem sendo utilizada para explicar a transferência de fotossintatos da parte aérea para a raiz e seu efeito sobre a produção. Quando um nutriente limita o crescimento vegetal, as raízes transformam-se em forte dreno de carboidratos, limitando o crescimento da parte aérea em relação à raiz (Araújo, 2000). Os resultados da relação parte aérea:raiz demonstram uma variação de 3,54 a 1,88 (Tabela 9). O cultivar BRSGO Jataí apresentou semelhança com os cultivares BRAS 98-5409, DM-118, IAC PL-1, IAC-24, IAC-23, DM-Vitória, BRAS 97-7371, M-Soy 9001. IAC-18, DM-247, IAC-19, BRS Celeste e DM-339, diferindo dos demais cultivares que apresentaram menor relação. Vinte e nove cultivares de soja foram avaliados e classificados quanto à resposta a concentrações de $\mathrm{P}$ em solução nutritiva $\mathrm{e}$ os cultivares eficientes e responsivos mostraram os maiores valores para matéria seca de parte aérea, matéria seca total e índice de eficiência, e os menores teores de $\mathrm{P}$ na parte aérea (Furlani et al., 2002).

$\mathrm{Na}$ avaliação desta relação é importante observar conjuntamente a participação da biomassa da parte aérea. Embora o cultivar BRSGO Jataí tenha uma das maiores relações, obteve, no entanto, o penúltimo menor valor entre os cultivares de soja, de biomassa da parte aérea neste estudo, com 1,83 $\mathrm{g}_{\text {planta }}{ }^{-1}$ (Tabela 7). Em trabalho realizado com feijoeiro observou-se ser uma espécie que apresenta baixa eficiência de absorção de $\mathrm{P}$, em virtude da pequena relação raiz:parte aérea e do baixo influxo, associados a um menor requerimento de $\mathrm{P}$ para a produção de biomassa (Föhse et al., 1988). Considerando as variáveis juntas é desejável que as plantas possuam um sistema radicular que explore o máximo possível o solo onde se encontra e, ao mesmo tempo, produza uma biomassa da parte aérea, equilibrado com o sistema radicular e que propicie uma boa produção. Neste contexto, os cultivares IAC PL-1, BRAS 97-7371, 
DM-247, DM-118 apresentaram a maior performance inclusive quando se considera a biomassa total (Tabela 10).

Tabela 7. Biomassa da parte aérea de trinta e dois cultivares de soja, acompanhados por dois cultivares controle, arroz e feijão guandu cultivado em solo LVA distrófico do cerrado marcado com ${ }^{32} \mathrm{P}$. (média de 3 repetições).

\begin{tabular}{|c|c|}
\hline \multirow{2}{*}{ Cultivar } & Biomassa parte aérea \\
\hline & 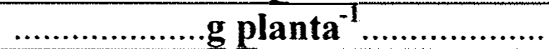 \\
\hline IAC PL-1 & $2,91 \mathrm{a}$ \\
\hline BRAS 97-7371 & $2,88 \mathrm{a}$ \\
\hline DM 118 & $2,66 \mathrm{ab}$ \\
\hline DM 247 & $2,56 \mathrm{abc}$ \\
\hline DM Vitória & $2,56 \mathrm{abcd}$ \\
\hline BRS Milena & 2,46 bcde \\
\hline IAC-23 & 2,44 bcde \\
\hline BRAS 95-30080 & 2,41 bcdef \\
\hline M-Soy 8001 & 2,35 bcdefg \\
\hline BRS Celeste & 2,34 bcdefg \\
\hline MG/BR 46 Conquista & 2,34 bcdefg \\
\hline IAC-24 & 2,33 bcdefg \\
\hline M-Soy 9001 & 2,31 bcdefg \\
\hline BRAS 98-5409 & 2,30 bcdefg \\
\hline BRAS 97-1368 & 2,28 bcdefg \\
\hline IAC-19 & 2,24 cdefg \\
\hline M-Soy 8400 & cdefgh \\
\hline M-Soy 6101 & cdefgh \\
\hline BRS Carla & cdefgh \\
\hline DM 339 & cdefgh \\
\hline IAC- 18 & defgh \\
\hline M-Soy 9350 & efghi \\
\hline DM Nobre & efghi \\
\hline $98 C 81$ & 2,04 \\
\hline BRS 133 & 2,03 \\
\hline BRSGO Bela Vista & 2,01 \\
\hline IAC 22 & 2,00 \\
\hline M-Soy 8866 & 1,99 \\
\hline M-Soy 8411 & 1,99 \\
\hline DM 309 & 1,99 \\
\hline BRSGO-Jataí & 1,83 \\
\hline EMGOPA 316 & 1,77 \\
\hline F. GUANDÚ & 0,68 \\
\hline Arroz & 1,03 \\
\hline C.V. $(\%)$ & 5,56 \\
\hline D.M.S. & 0,393 \\
\hline D.P.M. & 0,011 \\
\hline
\end{tabular}

Médias seguidas pelas mesmas letras não diferem entre si pelo teste de Tukey ao nível de 5 
Tabela. 8. Biomassa da raiz de trinta e dois cultivares de soja, acompanhados por dois cultivares controle, arroz e feijão guandu cultivado em solo LVA distrófico do cerrado. (média de 3 repetições).

\begin{tabular}{|c|c|}
\hline \multirow{2}{*}{ Cultivar } & Biomassa da raiz \\
\hline & 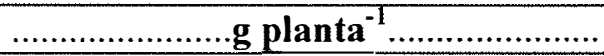 \\
\hline M-Soy 8001 & $1,09 \mathrm{a}$ \\
\hline M-Soy 8866 & $1,09 \mathrm{ab}$ \\
\hline BRS Milena & $1,01 \mathrm{abc}$ \\
\hline BRAS 97-7371 & $1,00 \mathrm{abc}$ \\
\hline M-Soy 8400 & $0,98 \mathrm{abc}$ \\
\hline BRAS 95-30080 & $0,96 \mathrm{abc}$ \\
\hline BRAS 97-1368 & $0,94 \mathrm{abc}$ \\
\hline IAC PL 1 & $0,93 \mathrm{abcd}$ \\
\hline M-Soy 6101 & $0,91 \mathrm{abcd}$ \\
\hline MG/BR 46 Conquista & $0,91 \mathrm{abcd}$ \\
\hline DM 247 & $0,89 \mathrm{abcd}$ \\
\hline M-Soy 9350 & $0,89 \mathrm{abcd}$ \\
\hline BRS Carla & $0,88 \mathrm{abcd}$ \\
\hline DM-Vitória & $0,88 \mathrm{abcd}$ \\
\hline IAC-22 & $0,86 \mathrm{abcd}$ \\
\hline EMGOPA 316 & $0,86 \mathrm{abcd}$ \\
\hline M-Soy 8411 & 0,83 bcd \\
\hline BRS Celeste & 0,83 bcd \\
\hline DM-118 & 0,83 bcd \\
\hline DM-Nobre & $0,81 \mathrm{~cd}$ \\
\hline M-Soy 9001 & $0,81 \mathrm{~cd}$ \\
\hline IAC-23 & $0,80 \mathrm{~cd}$ \\
\hline BRS 133 & $0,80 \mathrm{~cd}$ \\
\hline DM-309 & $0,80 \mathrm{~cd}$ \\
\hline IAC-19 & $0,79 \mathrm{~cd}$ \\
\hline DM-339 & $0,79 \mathrm{~cd}$ \\
\hline $98 C 81$ & $0,78 \mathrm{~cd}$ \\
\hline BRSGO Bela Vista & 0,77 cde \\
\hline IAC-18 & 0,76 cde \\
\hline IAC-24 & 0,76 cde \\
\hline BRAS 98-5409 & 0,68 de \\
\hline BRSGO-Jataí & $0,51 \quad \mathrm{e}$ \\
\hline F.GUANDÚ & $0,23 \quad f$ \\
\hline Arroz & $0,81 \mathrm{~cd}$ \\
\hline C.V. $(\%)$ & 9,77 \\
\hline D.M.S. & 0,266 \\
\hline D.P.M. & 0,00809 \\
\hline
\end{tabular}

Médias seguidas pelas mesmas letras não diferem entre si pelo teste de Tukey ao nível de 5 
Tabela 9. Valores médios da relação parte aérea:raiz, medidos nos trinta e dois cultivaresde soja, acompanhados por dois cultivares controle, arroz e feijão guandu, cultivados em solo LVA distrófico do cerrado. (média de 3 repetições).

\begin{tabular}{|c|c|}
\hline Cultivar & Relação parte aérea:raiz \\
\hline BRSGO-Jataí & $3,54 \mathrm{a}$ \\
\hline BRAS 98-5409 & $3,41 \mathrm{ab}$ \\
\hline DM-118 & $3,22 \mathrm{abc}$ \\
\hline IAC PL 1 & $3,15 \mathrm{abcd}$ \\
\hline IAC-24 & $3,10 \mathrm{abcde}$ \\
\hline IAC-23 & 3,08abcde \\
\hline DM-Vitória & 2,93 abcdef \\
\hline BRAS 97-7371 & 2,9labcdef \\
\hline M-Soy 9001 & $2,87 \mathrm{abcdef}$ \\
\hline IAC-18 & $2,86 \mathrm{abcdef}$ \\
\hline DM 247 & $2,85 \mathrm{abcdef}$ \\
\hline IAC-19 & $2,85 \mathrm{abcdef}$ \\
\hline BRS Celeste & $2,84 \mathrm{abcdef}$ \\
\hline DM-339 & $2,75 \mathrm{abcdefg}$ \\
\hline $98 C 81$ & 2,65 bcdefg \\
\hline M-Soy 9350 & 2,64 bcdefg \\
\hline BRSGO Bela Vista & 2,63 bcdefg \\
\hline DM-Nobre & 2,60 bcdefg \\
\hline MG/BR 46 Conquista & 2,58 bcdefg \\
\hline BRS 133 & 2,53 bcdefg \\
\hline BRAS 95-30080 & 2,51 cdefg \\
\hline DM-309 & 2,51 cdefg \\
\hline BRS Carla & 2,51 cdefg \\
\hline BRS Milena & 2,44 cdefg \\
\hline M-Soy 6101 & 2,43 cdefg \\
\hline BRAS 97-1368 & 2,42 cdefg \\
\hline IAC-22 & 2,34 cdefg \\
\hline M-Soy 8411 & 2,32 defg \\
\hline M-Soy 8400 & 2,27 defg \\
\hline M-Soy 8001 & 2,23 efg \\
\hline EMGOPA 316 & 2,06 \\
\hline M-Soy 8866 & $1,88 \quad \mathrm{gh}$ \\
\hline F. GUANDU & $3,02 \mathrm{abcde}$ \\
\hline Arroz & 1,27 \\
\hline C.V.(\%) & 10,38 \\
\hline D.M.S. & 0,896 \\
\hline D.P.M. & 0,027 \\
\hline
\end{tabular}

Médias seguidas pelas mesmas letras não diferem entre si pelo teste de Tukey ao nível de 5 
Ocorreram diferenças $(P<0,05)$ para a porcentagem de colonização micorrízica entre os cultivares de soja, o feijão guandu e o arroz (Tabela 11). A porcentagem de colonização variou de 64,6 (BRSGO Bela Vista) a 36,5\% (DM-339). Em condições subótimas de P no solo, a quantidade de Pi metabólico nas folhas ainda não atingiu níveis ótimos, a concentração de Pi é menor que a de Po, a planta aumenta sua atividade metabólica, incluindo-se a fotossíntese e a síntese de sacarose, produz mais fotoassimilados para uso em crescimento da parte aérea e raízes. Nessa condição de deficiência, grande parte do $\mathrm{P}$ absorvido é retida nas raízes, antes de ser translocado para a parte aérea. Dessa forma, as raízes passam a representar um dreno de maior força, maior atividade, onde o fluxo de compostos de carbono para esse dreno é maior. Esse fluxo seria usado para o crescimento das raízes e do fungo afetando a eficiência de utilização dos nutrientes. Neste experimento a colonização micorrízica não serviu como indicador da eficiência simbiótica, não se correlacionando com nenhum indicador de absorção ou utilização de fósforo, fato semelhante a este é mencionado por Yan et al. (1995). 
Tabela 10. Biomassa total em trinta e dois cultivares de plantas de soja, acompanhados por dois cultivares controle, arroz e feijão guandu, cultivados em solo LVA distrófico do cerrado.(média de 3 repetições).

\begin{tabular}{|c|c|}
\hline \multirow{2}{*}{ Cultivar } & Biomassa \\
\hline & 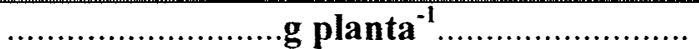 \\
\hline BRAS $97-7371$ & $3,87 \mathrm{a}$ \\
\hline IAC PL-1 & $3,84 \mathrm{a}$ \\
\hline DM-118 & $3,48 \mathrm{ab}$ \\
\hline BRS Milena & $3,47 \mathrm{abc}$ \\
\hline DM-247 & $3,45 \mathrm{abcd}$ \\
\hline M-Soy 8001 & $3,45 \mathrm{abcd}$ \\
\hline DM-Vitória & $3,43 a b c d$ \\
\hline BRAS $95-30080$ & 3,37abcde \\
\hline MG/BR 46 Conquista & 3,25 bcdef \\
\hline IAC-23 & 3,24 bcdef \\
\hline BRAS 97-1368 & 3,22 bcdef \\
\hline M-Soy 8400 & 3,20 bcdef \\
\hline BRS Celeste & 3,17 bcdefg \\
\hline M-Soy 6101 & 3,12 bcdefg \\
\hline M-Soy 9001 & 3,12 bcdefg \\
\hline BRS Carla & 3,08 bcdefg \\
\hline IAC-24 & 3,08 bcdefg \\
\hline M-Soy 8866 & 3,08 bcdefg \\
\hline IAC-19 & 3,03 bcdefg \\
\hline M-Soy 9350 & 3,00 bcdefg \\
\hline BRAS 98-5409 & 2,98 bcdefg \\
\hline DM-339 & 2,97 bcdefg \\
\hline IAC-18 & 2,93 cdefg \\
\hline DM-Nobre & 2,91 defg \\
\hline IAC-22 & 2,86 \\
\hline BRS 133 & 2,83 \\
\hline $98 C 81$ & efgh \\
\hline M-Soy 8411 & efgh \\
\hline DM-309 & 2,78 \\
\hline BRSGO Bela Vista & 2,78 \\
\hline EMGOPA 316 & 2,62 \\
\hline BRSGO Jataí & 2,34 \\
\hline F.GUANDÚ & 0,91 \\
\hline Arroz & 1,84 \\
\hline C.V.(\%) & 5,64 \\
\hline D.M.S. & 0,55 \\
\hline D.P.M. & 0,016 \\
\hline
\end{tabular}

Médias seguidas pelas mesmas letras não diferem entre si pelo teste de Tukey ao nível de 5 
Tabela 11. Dados de colonização micorrizica em raízes de trinta e dois cultivares de soja e respectivos controles, cultivados em solo LVA distrófico do cerrado.(média de 3 repetições).

\begin{tabular}{|c|c|}
\hline \multirow{2}{*}{ Cultivar } & Colonização micorrízica \\
\hline & 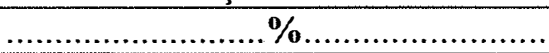 \\
\hline BRSGO Bela Vista & $64,6 \mathrm{a}$ \\
\hline EMGOPA 316 & $63,5 \mathrm{a}$ \\
\hline M-Soy 8001 & $63,1 \mathrm{a}$ \\
\hline BRS Carla & $61,8 \mathrm{a}$ \\
\hline BRS Celeste & $61,7 a$ \\
\hline IAC 19 & $61,4 a$ \\
\hline IAC 23 & $59.6 \mathrm{a}$ \\
\hline DM-247 & $59,5 \mathrm{a}$ \\
\hline IAC-24 & $59,4 \mathrm{a}$ \\
\hline BRAS $95-30080$ & $58,9 \mathrm{a}$ \\
\hline BRS Milena & $58,7 \mathrm{a}$ \\
\hline M-Soy 8400 & $58,6 \mathrm{ab}$ \\
\hline M-Soy 6101 & $58,5 \mathrm{ab}$ \\
\hline BRAS 97-7371 & $57,2 \mathrm{abc}$ \\
\hline BRS 133 & $57,2 \mathrm{abc}$ \\
\hline DM-309 & $56,4 \mathrm{abc}$ \\
\hline MG/BR 46 Conquista & $56,4 \mathrm{abc}$ \\
\hline BRSGO Jataí & $56,2 \mathrm{abc}$ \\
\hline BRAS 97-1368 & $55,9 \mathrm{abc}$ \\
\hline IAC-18 & $54,7 \mathrm{abc}$ \\
\hline $98 \mathrm{C} 81$ & $54,6 a b c$ \\
\hline IAC PL-1 & $53,6 \mathrm{abc}$ \\
\hline DM-118 & $52,8 \mathrm{abc}$ \\
\hline DM Vitória & $51,8 \mathrm{abc}$ \\
\hline BRAS 98-5409 & $51,8 \mathrm{abc}$ \\
\hline M-Soy 9001 & $51,7 \mathrm{abc}$ \\
\hline IAC-22 & $51,1 \mathrm{abc}$ \\
\hline DM-Nobre & $50,7 \mathrm{abc}$ \\
\hline M-Soy 8866 & $47,8 \mathrm{abc}$ \\
\hline M-Soy 8411 & $47,5 \mathrm{abc}$ \\
\hline M-Soy 9350 & $37,5 \mathrm{bc}$ \\
\hline DM-339 & $36,5 \quad \mathrm{c}$ \\
\hline F. GUANDÚ & $60,5 a$ \\
\hline Arroz & $60,1 \mathrm{a}$ \\
\hline C.V.(\%) & 11,67 \\
\hline D.M.S. & 21,13 \\
\hline D.P.M. & 0,64 \\
\hline
\end{tabular}

Médias seguidas pelas mesmas letras não diferem entre si pelo teste de Tukey ao nível de 5 


\subsubsection{Concentração e conteúdo de $P$ na parte aérea e na raiz}

A concentração de $P$ na parte aérea e na raiz foi variável $(P<0,05)$ entre os cultivares de soja, feijão guandu e arroz (Tabela 12). A concentração de P no sistema radicular dos cultivares foi maior que a concentração de $\mathrm{P}$ da parte aérea. $\mathrm{O}$ cultivar IAC PL-1 que apresentou um dos maiores valores de biomassa da parte aérea (Tabela 7), apresentou uma das menores concentrações de $\mathrm{P}$ tanto na parte aérea como na raiz. Diferentemente, os cultivares BRSGO Jataí e IAC 18 que apresentaram maiores valores de concentração de $\mathrm{P}$ na parte aérea e na raiz, apresentaram valores de biomassa menores do que cultivares como IAC PL-1 e BRAS 97-7371. Este contraste demonstra o desequilíbrio existente entre os cultivares BRSGO Jataí e IAC-18 entre a quantidade de $\mathrm{P}$ absorvido e o efeito do nutriente no metabolismo e na produção de biomassa. A maior concentração de $\mathrm{P}$ tanto na parte aérea quanto na raiz não está se refletindo na biomassa.

$\mathrm{O} P$ possui uma importante função sobre a distribuição de matéria seca entre as raízes e a parte aérea. Numa condição de deficiência de $\mathrm{P}$, a menor relação parte aérea / raiz resulta de uma alteração morfológica que contribui para aumentar a superfície radicular de absorção (Aung, 1974) e nesta condição de deficiência de $\mathrm{P}$ as raízes transformam-se em forte dreno de carboidratos, causando limitação no crescimento da parte aérea do que da raiz (Clarkson, 1985).

Os valores acumulados de $\mathrm{P}$ na parte aérea foram significativos $(P<0,05)$, tendo o cultivar M-Soy 8411 apresentado a menor quantidade de P acumulado em relação aos cultivares BRAS 97-7371 e IAC-18 (Tabela 13). O cultivar IAC-18, embora tenha apresentado uma biomassa de raiz de $0,76 \mathrm{~g} \mathrm{planta}^{-1}$ (Tabela 8), das mais baixas e uma mediana produção de biomassa da parte aérea (Tabela 7), proporcionou um dos maiores acúmulos de $\mathrm{P}$ na parte aérea demonstrando boa capacidade de transportar o $\mathrm{P}$ absorvido da raiz para a parte aérea, contudo não demonstrando esta capacidade na maior produção de biomassa da parte aérea. 
Tabela. 12. Concentração de $\mathrm{P}(\mathrm{g} / \mathrm{kg})$ na biomassa da parte aérea e da raiz em trinta e dois cultivares de soja, acompanhados por dois cultivares controle arroz e feijão guandu cultivados em solo LVA distrófico marcado com ${ }^{32} \mathrm{P}$. (média de 3 repetições).

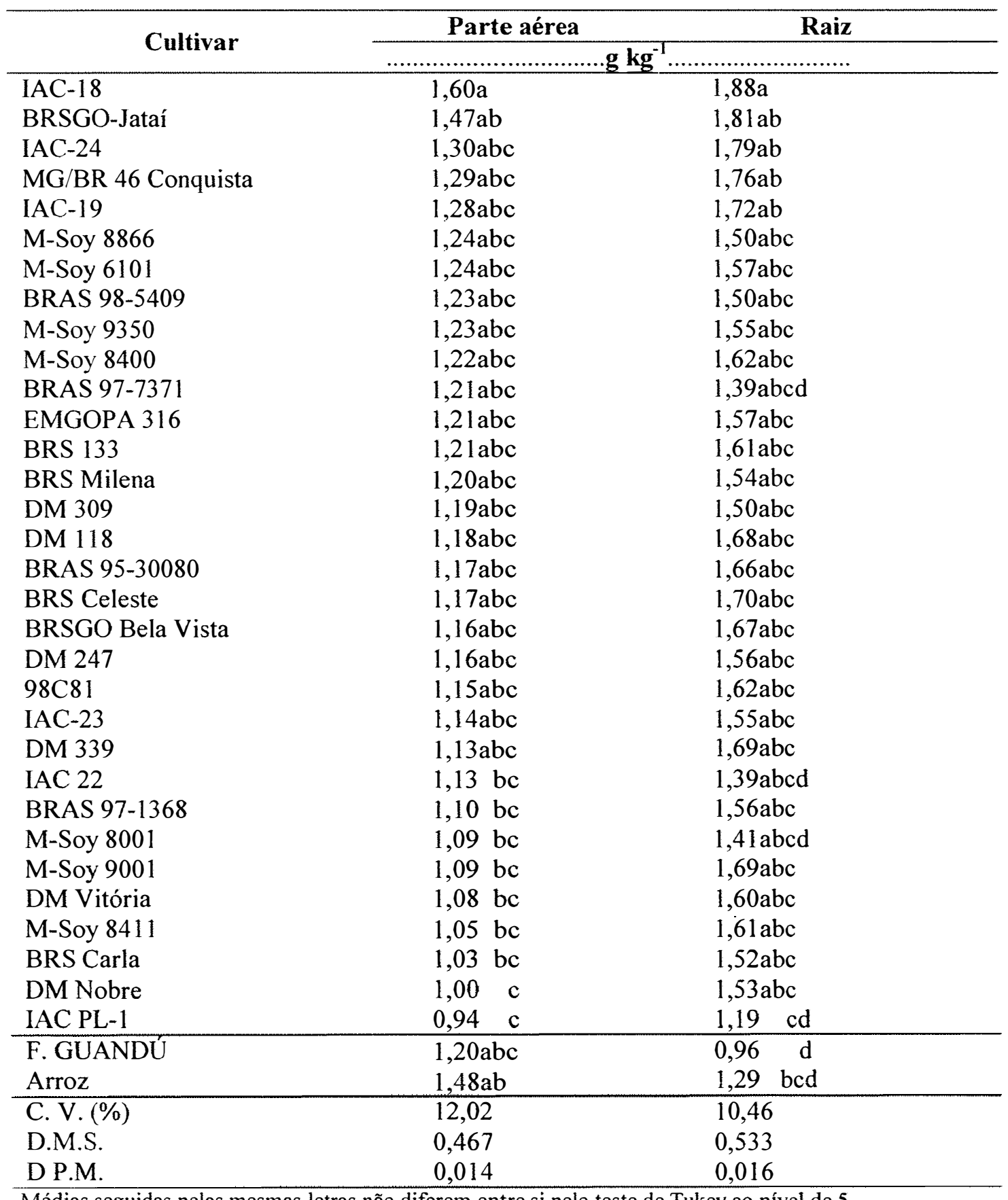

Médias seguidas pelas mesmas letras não diferem entre si pelo teste de Tukey ao nível de 5 
Tabela 13. Valores de $\mathrm{P}$ total da parte aérea de trinta e dois cultivares de soja, acompanhados por dois cultivares controle, arroz e feijão guandu, cultivados em solo LVA distrófico do cerrado.(média de 3 repetições).

\begin{tabular}{|c|c|}
\hline \multirow{2}{*}{ Cultivar } & P total Parte aérea \\
\hline & 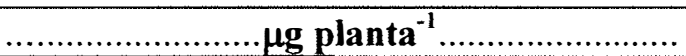 \\
\hline BRAS 97-7371 & $3477,4 \mathrm{a}$ \\
\hline IAC-18 & $3464,6 \mathrm{a}$ \\
\hline DM-118 & $3135,6 \mathrm{ab}$ \\
\hline IAC-24 & $3038,7 \mathrm{abc}$ \\
\hline MG/BR 46 Conquista & $3014,6 \mathrm{abc}$ \\
\hline DM 247 & $2962,5 \mathrm{abc}$ \\
\hline BRS Milena & $2954,3 \mathrm{abc}$ \\
\hline IAC-19 & $2880,7 \mathrm{abc}$ \\
\hline BRAS 98-5409 & $2839,1 \mathrm{abc}$ \\
\hline BRAS 95-30080 & $2828,3 \mathrm{abc}$ \\
\hline IAC-23 & $2788,0 \mathrm{abc}$ \\
\hline DM-Vitória & $2770,3 \mathrm{abc}$ \\
\hline IAC PL-1 & $2750,8 \mathrm{abc}$ \\
\hline BRS Celeste & $2735,6 a b c$ \\
\hline M-Soy 6101 & $2708,5 \mathrm{abc}$ \\
\hline BRSGO Jataí & $2689,1 \mathrm{abc}$ \\
\hline M-Soy 8400 & $2665,2 \mathrm{abc}$ \\
\hline M-Soy 9350 & $2592,1 \mathrm{abc}$ \\
\hline M-Soy 8001 & $2575,6 \mathrm{abc}$ \\
\hline M-Soy 9001 & $2525,3 \mathrm{abcd}$ \\
\hline BRAS 97-1368 & $2493,2 \mathrm{abcd}$ \\
\hline M-Soy 8866 & $2472,5 \mathrm{abcd}$ \\
\hline DM-339 & $2462,7 \mathrm{abcd}$ \\
\hline BRS 133 & $2457,2 \mathrm{abcd}$ \\
\hline DM-309 & $2372,5 \mathrm{bcd}$ \\
\hline $98 \mathrm{C} 81$ & $2339,7 \mathrm{bcd}$ \\
\hline BRSGO Bela Vista & $2329,2 \mathrm{bcd}$ \\
\hline IAC-22 & $2258,4 \mathrm{bcd}$ \\
\hline BRS Carla & $2252,3 \mathrm{bcd}$ \\
\hline EMGOPA 316 & $2137,7 \mathrm{bcd}$ \\
\hline DM-Nobre & $2106,3 \mathrm{bcd}$ \\
\hline M-Soy 8411 & $2092,5 \mathrm{~cd}$ \\
\hline F. GUANDU & $812,0 \quad \mathrm{e}$ \\
\hline Arroz & 1515,8 \\
\hline C.V.(\%) & 12,42 \\
\hline D.M.S. & 1040,2 \\
\hline D.P.M. & 31,635 \\
\hline
\end{tabular}

Médias seguidas pelas mesmas letras não diferem entre si pelo teste de Tukey ao nível de $5 \%$ 
Tabela 14. Valores de P total da raiz de trinta e dois cultivares de soja, acompanhados por dois cultivares controle, arroz e feijão guandu, cultivados em solo LVA distrófico do cerrado.(médias de 3 repetições).

\begin{tabular}{|c|c|}
\hline \multirow{2}{*}{ Cultivar } & P total Raiz \\
\hline & 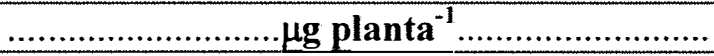 \\
\hline M-Soy 8866 & $1625,1 \mathrm{a}$ \\
\hline MG/BR 46 Conquista & $1595,7 \mathrm{ab}$ \\
\hline BRAS $95-30080$ & $1588,7 \mathrm{ab}$ \\
\hline M-Soy 8400 & - $1588,5 \mathrm{ab}$ \\
\hline BRS Milena & $1553,5 \mathrm{ab}$ \\
\hline M-Soy 8001 & $1546,5 \mathrm{ab}$ \\
\hline BRAS 97-1368 & $1470,5 \mathrm{abc}$ \\
\hline IAC-18 & $1423,8 \mathrm{abc}$ \\
\hline M-Soy 6101 & $1417,8 \mathrm{abc}$ \\
\hline DM-Vitória & $1411,2 \mathrm{abc}$ \\
\hline BRS Celeste & $1400,3 \mathrm{abc}$ \\
\hline DM-247 & $1400,1 \mathrm{abc}$ \\
\hline BRAS 97-7371 & $1389,9 \mathrm{abc}$ \\
\hline DM-118 & $1383,2 \mathrm{abc}$ \\
\hline M-Soy 9350 & $1380,1 \mathrm{abc}$ \\
\hline M-Soy 9001 & $1364,0 \mathrm{abc}$ \\
\hline IAC-19 & $1358,2 \mathrm{abc}$ \\
\hline IAC-24 & $1351,1 \mathrm{abc}$ \\
\hline M-Soy 8411 & $1350,5 \mathrm{abc}$ \\
\hline EMGOPA 316 & $1345,8 \mathrm{abc}$ \\
\hline BRS Carla & $1337,8 \mathrm{abc}$ \\
\hline DM-339 & $1335,1 \mathrm{abc}$ \\
\hline BRS 133 & $1290,1 \mathrm{abc}$ \\
\hline BRSGO Bela Vista & $1283,9 \mathrm{abc}$ \\
\hline $98 C 81$ & $1269,7 \mathrm{abc}$ \\
\hline IAC-23 & $1253,6 a b c$ \\
\hline DM-Nobre & $1245,3 \mathrm{abc}$ \\
\hline IAC-22 & $1196,7 \mathrm{abc}$ \\
\hline DM-309 & $1183,9 \mathrm{abc}$ \\
\hline IAC PL-1 & $1108,0 \mathrm{abc}$ \\
\hline BRAS 98-5409 & $1021,6 \mathrm{bc}$ \\
\hline BRSGO Jataí & $930,8 \quad \mathrm{c}$ \\
\hline F. GUANDÚ & $220,4 \quad d$ \\
\hline Arroz & $1048,0 \mathrm{abc}$ \\
\hline C.V. $(\%)$ & 14,03 \\
\hline D.M.S. & 599,91 \\
\hline D.P.M. & 18,245 \\
\hline
\end{tabular}

Médias seguidas pelas mesmas letras não diferem entre si pelo teste de Tukey ao nível de $5 \%$ 
Com relação ao $\mathrm{P}$ acumulado da raiz verifica-se uma variação de 1625,1 (M-Soy 8866) a $930,8 \mu$ g planta $^{-1}$ (BRSGO Jataí) entre os cultivares de soja, representando uma diferença significativa $(P<0,05)$, sendo que o arroz apresentou posição intermediária e o guandu o que apresentou menor quantidade de $\mathrm{P}$ acumulado (Tabela 14). Com o objetivo de estudar a translocação de P em três cultivares de soja sob diferentes níveis de P, Martinez et al. (1993) encontraram plantas que, em solo com baixa disponibilidade em $\mathrm{P}$, com nível nutricional baixo tiveram maior retenção de $\mathrm{P}$ absorvido nas raízes que plantas com nível nutricional elevado demonstrando que a homeostase radicular tem preferência em relação à da parte aérea.

\subsubsection{Cálculo da Atividade específica (S)}

Os valores da atividade específica obtidos para os cultivares de soja, feijão e

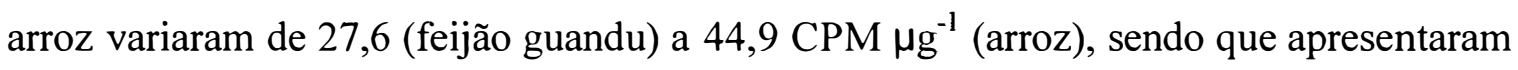
diferenças significativa $(P<0,05)$. As atividades específicas para o arroz e o feijão guandu estão de acordo com o trabalho de Fernandes (2001). Entre os cultivares de soja que apresentaram menor atividade específica destaca-se o BRAS $977371 \mathrm{com} 31 \mathrm{CPM}$ $\mathrm{\mu g}^{-1}$, diferindo dos cultivares DM-309, IAC-23, BRS 133, 98C81, BRS CARLA e M-

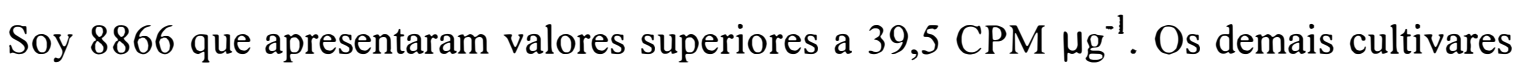
não diferiram entre si e do BRAS 97-7371. Uma menor atividade específica, de acordo com Hocking et al. (1997), indica que a planta é mais capaz de acessar o fósforo pouco disponível do solo. Esta melhor eficiência pode ser atribuída a diversos fatores, como formação de raízes proteóides, observadas em tremoço branco, liberação de ácidos orgânicos pelo sistema radicular que ocorre por exemplo, no feijão guandu. Fernandes (2001) avaliou a atividade específica de vinte e duas espécies de plantas em amostras de Latossolo Vermelho Amarelo distrófico marcado $\operatorname{com}^{32} \mathrm{P}$ e obteve valores da atividade 
Tabela 15. Resultados da atividade específica (S) de ${ }^{32} \mathrm{P}$ extraído da parte aérea de trinta e dois cultivares de soja e respectivos controles, cultivados em solo LVA distrófico do cerrado.(média de 3 repetições).

\begin{tabular}{|c|c|}
\hline \multirow{2}{*}{ Cultivar } & Atividade Específica \\
\hline & 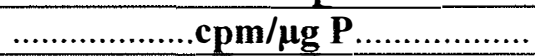 \\
\hline DM-309 & $40,5 \mathrm{ab}$ \\
\hline IAC-23 & $40,4 a b$ \\
\hline BRS 133 & $40,3 \mathrm{ab}$ \\
\hline $98 \mathrm{C} 81$ & $40,3 \mathrm{ab}$ \\
\hline BRS Carla & $39,8 \mathrm{abc}$ \\
\hline M-Soy 8866 & $39,5 \mathrm{abc}$ \\
\hline DM-118 & $38,8 \mathrm{abcd}$ \\
\hline DM Vitória & $38,5 \mathrm{abcd}$ \\
\hline BRSGO Jataí & $38,4 \mathrm{abcd}$ \\
\hline M-Soy 8411 & $38,3 \mathrm{abcd}$ \\
\hline IAC-19 & $37,7 \mathrm{abcd}$ \\
\hline DM-339 & 37,5 abcd \\
\hline IAC-18 & $37,4 \mathrm{abcd}$ \\
\hline M-Soy 9001 & 37,3 abcd \\
\hline IAC-24 & $37,0 \mathrm{abcd}$ \\
\hline BRAS 97-1368 & $36,7 \mathrm{abcd}$ \\
\hline BRAS 95-30080 & $36,7 \mathrm{abcd}$ \\
\hline BRS Celeste & $36,3 \mathrm{bcd}$ \\
\hline M-Soy 6101 & $36,0 \mathrm{bcd}$ \\
\hline IAC-22 & 35,7 bcde \\
\hline BRAS 985409 & 35,7 bcde \\
\hline M-Soy 9350 & 35,5 bcde \\
\hline DM-247 & 35,1 bcde \\
\hline MG/BR 46 Conquista & 34,8 bcde \\
\hline EMGOPA 316 & 34,7 bcde \\
\hline M-Soy 8001 & 34,0 bcde \\
\hline DM-Nobre & 33,8 bcde \\
\hline IAC PL-1 & 33,5 bcde \\
\hline M-Soy 8400 & 33,4 bcde \\
\hline BRS Milena & 32,3 bcde \\
\hline BRSGO Bela Vista & 31,6 cde \\
\hline BRAS $97-7371$ & 31,0 de \\
\hline F. GUANDU & 27,6 \\
\hline Arroz & $44,9 \mathrm{a}$ \\
\hline C.V. $(\%)$ & 6,97 \\
\hline D.M.S. & 8,28 \\
\hline D.P.M. & 0,25 \\
\hline
\end{tabular}

Médias seguidas pelas mesmas letras não diferem entre si pelo teste de Tukey ao nível de $5 \%$ 
específica variando de 27,8 a $150 \mathrm{CPM} \mu \mathrm{g}^{-1}$ respectivamente, para o guandu e crotalária. A atividade específica para soja, cultivar celeste, obtida neste experimento realizado por

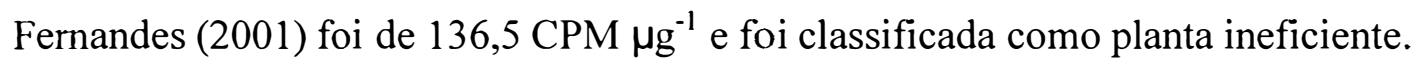

A soja é tida como planta não secretora ou pouco secretora de ácidos orgânicos diferentemente do guandu (Cajanus cajan L.) e o tremoço branco (Lupinus albus) que secretam grande quantidade de ácidos orgânicos, entre eles, o ácido cítrico pelos protéoides das raízes do tremoço branco e ácido malônico e piscídico pelo feijão guandu (Otani et al., 1996; Hocking \& Randal, 2001).

A busca de cultivares que venham a produzir ácidos orgânicos objetivando aumento na eficiência de absorção de fósforo fortalecerá a produtividade em áreas com baixa disponibilidade deste nutriente. Como neste experimento não se utilizou doses de P para avaliar a resposta dos cultivares não é possível aplicar a classificação utilizada por Furlani et al. (2002), resolveu-se classificar com base na atividade específica, os cultivares de soja estudados, em dois grupos distintos: grupo 1 (Eficientes) - aqueles que em baixa disponibilidade de $\mathrm{P}$ apresentou baixa atividade específica (valor menor que 35 $\mathrm{CPM} \mu \mathrm{g}^{-1}$ ) e, grupo 2 (Ineficientes) - aqueles cultivares com maior atividade específica,

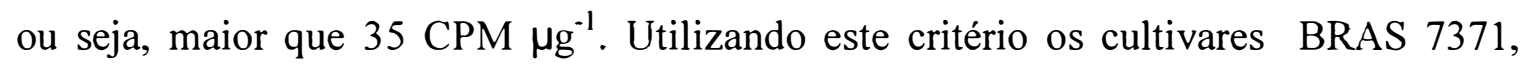
BRSGO Bela Vista, BRS Milena, M-Soy 8400, IAC PL-1, DM-Nobre, M-Soy 8001, EMGOPA 316 e MG/BR 46 Conquista, são classificados como eficientes e os demais

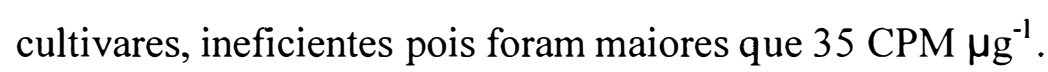

\subsubsection{Razão de eficiência radicular (RER)}

Os resultados da razão de eficiência radicular (RER) foram variáveis $(P<0.05)$ tanto entre os cultivares de soja como entre o feijão guandu e arroz. Os valores da RER encontrados para os cultivares de soja variaram de 2,34 (M-Soy 8866) a 4,80 $\mathrm{mg} \mathrm{de} \mathrm{P} \mathrm{g}^{-1}$ de matéria seca (BRSGO Jataí) (Tabela 16). A RER para o feijão guandu e o arroz foram respectivamente, 3,62 e 1,83 $\mathrm{mg}$ de $\mathrm{P} \mathrm{g}^{-1}$ de matéria seca. A habilidade que as plantas apresentam na absorção de $\mathrm{P}$ do solo com baixa disponibilidade neste nutriente, pode também ser avaliada pela razão de eficiência radicular, um indicador que tem sido 
Tabela 16. Razão de eficiência radicular, obtida dos trinta e dois cultivares de soja, e respectivos controles, cultivados em solo LVA distrófico do cerrado.(média de 3 repetições).

\begin{tabular}{|c|c|}
\hline \multirow{2}{*}{ Cultivar } & Razão de eficiência radicular \\
\hline & 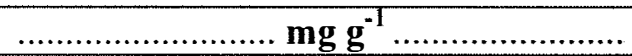 \\
\hline BRSGO Jataí & $4,80 \mathrm{a}$ \\
\hline BRAS 98-5409 & $4,38 \mathrm{ab}$ \\
\hline IAC-24 & $4,03 \mathrm{abc}$ \\
\hline IAC-18 & $3,93 \mathrm{abcd}$ \\
\hline IAC-19 & 3,66 bcde \\
\hline DM-118 & 3,60 bcde \\
\hline IAC-23 & 3,49 bcde \\
\hline DM-309 & 3,43 bcdef \\
\hline MG/BR 46 Conquista & 3,36 bcdef \\
\hline BRS Celeste & 3,32 bcdef \\
\hline DM-247 & 3,31 bcdef \\
\hline DM-Vitória & 3,18 cdef \\
\hline M-Soy 9001 & 3,16 cdef \\
\hline DM-339 & 3,12 cdef \\
\hline BRS 133 & 3,07 cdef \\
\hline $98 C 81$ & 3,04 cdef \\
\hline IAC PL-1 & 3,04 cdef \\
\hline BRSGO Bela Vista & 3,03 cdef \\
\hline M-Soy 6101 & 3,01 cdef \\
\hline BRS Milena & 2,93 cdefg \\
\hline M-Soy 9350 & 2,92 cdefg \\
\hline BRAS $95-30080$ & 2,84 defg \\
\hline M-Soy 8400 & 2,78 efg \\
\hline BRS Carla & 2,76 \\
\hline BRAS 97-1368 & 2,67 \\
\hline IAC-22 & 2,63 \\
\hline DM-Nobre & 2,59 \\
\hline BRAS $97-7371$ & 2,58 \\
\hline M-Soy 8411 & 2,57 \\
\hline EMGOPA 316 & 2,56 \\
\hline M-Soy 8001 & 2,35 \\
\hline M-Soy 8866 & $2,34 \quad f g$ \\
\hline F. GUANDU & 3,62 bcde \\
\hline Arroz & 1,83 \\
\hline C.V.(\%) & 11,08 \\
\hline D.M.S. & 1,12 \\
\hline D.P.M. & 0,034 \\
\hline
\end{tabular}

Médias seguidas pelas mesmas letras não diferem entre si pelo teste de Tukey ao nível de $5 \%$ 
proposto para programas de melhoramento (Jones et al., 1989) e segundo Batten (1992), ainda é pouco reportado ou utilizado. Em trabalho realizado com cultivares de trigo Jones et al. (1989) encontraram que em solos onde se aplicou $2 \mathrm{~kg} \mathrm{P} \mathrm{ha}^{-1}$ os valores de razão de eficiência radicular variaram de 5 a $10,6 \mathrm{mg} \mathrm{P} \mathrm{g}^{-1}$, tendo os genótipos mais altos absorvido mais $\mathrm{P}$, em média, do que os genótipos semi-anões e quando se aplicou $40 \mathrm{~kg} \mathrm{P} \mathrm{ha}^{-1}$ os valores da razão de eficiência radicular variaram de 9,7 a $21,2 \mathrm{mg} \mathrm{P} \mathrm{g}^{-1}$, não havendo mais diferenças entre os genótipos estudados. Este indicador proposto para ser utilizado em programas de melhoramento para obtenção de cultivares eficientes em $\mathrm{P}$, considera como denominador a biomassa do sistema radicular e cuidados devem ser tomados no processo de seleção para eficiência de P principalmente em condições de baixa disponibilidade de P. Nesta condição pode-se ter cultivares que produzam baixa produção de biomassa de raiz provocando um alto valor na razão de eficiência radicular mesmo tendo uma biomassa da parte aérea baixa em relação a outros cultivares. Pelo exposto, torna-se imprescindível que outros indicadores sejam considerados na seleção.

A Tabela 16 mostra que os cultivares BRSGO Jataí, BRAS 98-5409, IAC-24 e IAC-18 apresentaram valores de razão de eficiência radicular superiores aos cultivares M-Soy 8866, M-Soy 8001, EMGOPA 316, M-Soy 8411, BRAS 977371 , DM-Nobre, IAC-22, BRAS 97-1368, BRS-Carla e M-Soy 8400. Os cultivares que apresentaram valores superiores neste indicador foram exatamente aqueles que apresentaram biomassa radicular menor que os demais cultivares (Tabela 8). Em condição de solução nutritiva Martinez et al.(1993) trabalharam com três cultivares de soja e três doses de P e constataram aumento na eficiência de absorção com o aumento das doses de P.

\subsection{5 Índice de utilização de fósforo (IUP)}

Os cultivares de soja, feijão guandu e arroz que cresceram na mesma condição de disponibilidade de $\mathrm{P}$ mostraram comportamento diferenciado no índice de utilização de fósforo (IUP) considerando o nível de $5 \%$ de probabilidade (Tabela 17). Os valores de IUP variaram de 3,24 a $1,36 \mathrm{~g}^{2} \mathrm{mg}^{-1}$, respectivamente para os cultivares BRAS 97-7371 e BRSGO Jataí. Os cultivares que apresentaram o maior IUP foram BRAS 97-7371 e 
Tabela 17. Índice de utilização de Fósforo (IUP) nos trinta e dois cultivares de soja, e respectivos controles, cultivados em solo LVA distrófico do cerrado.(média de 3 repetições).

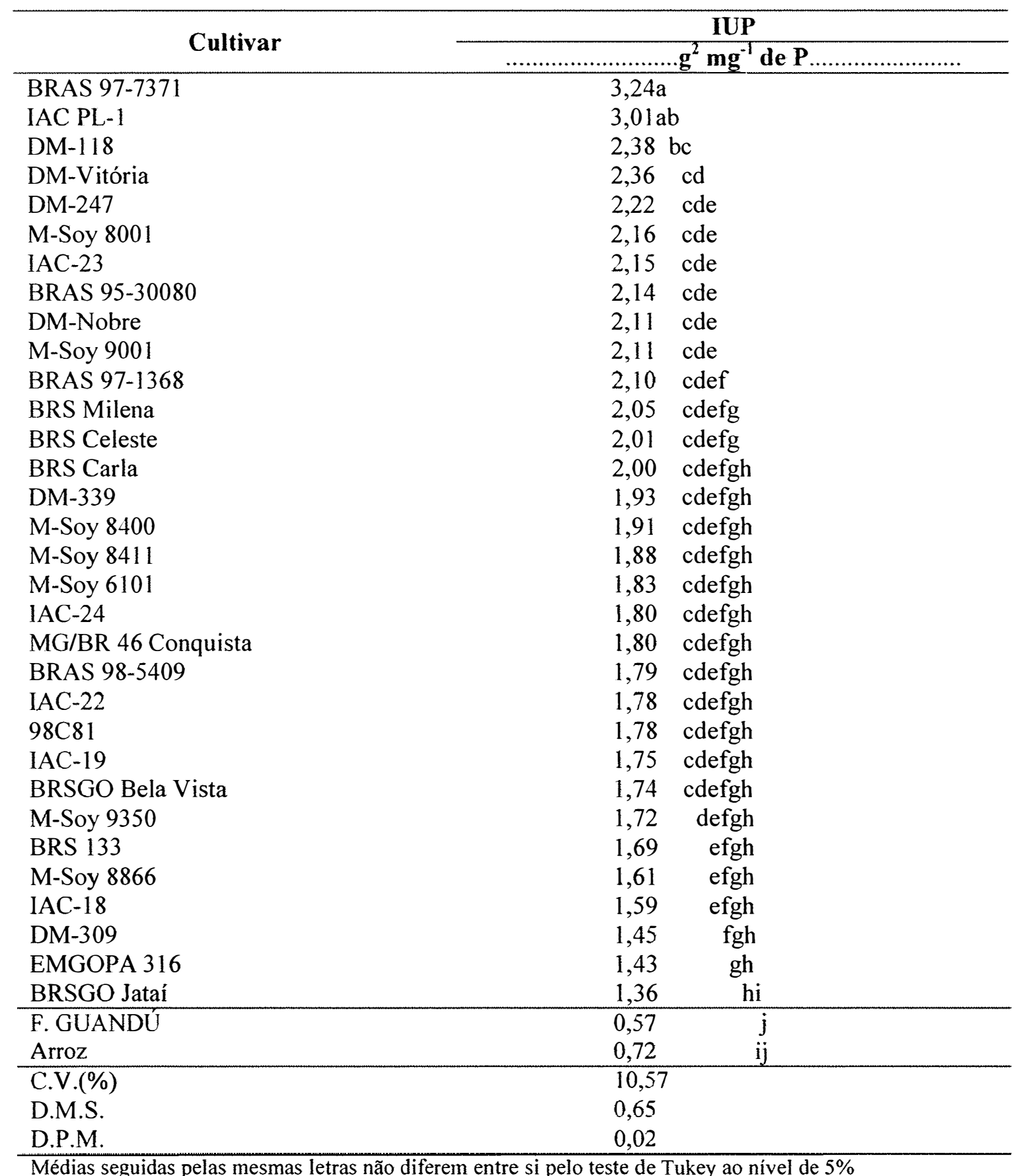




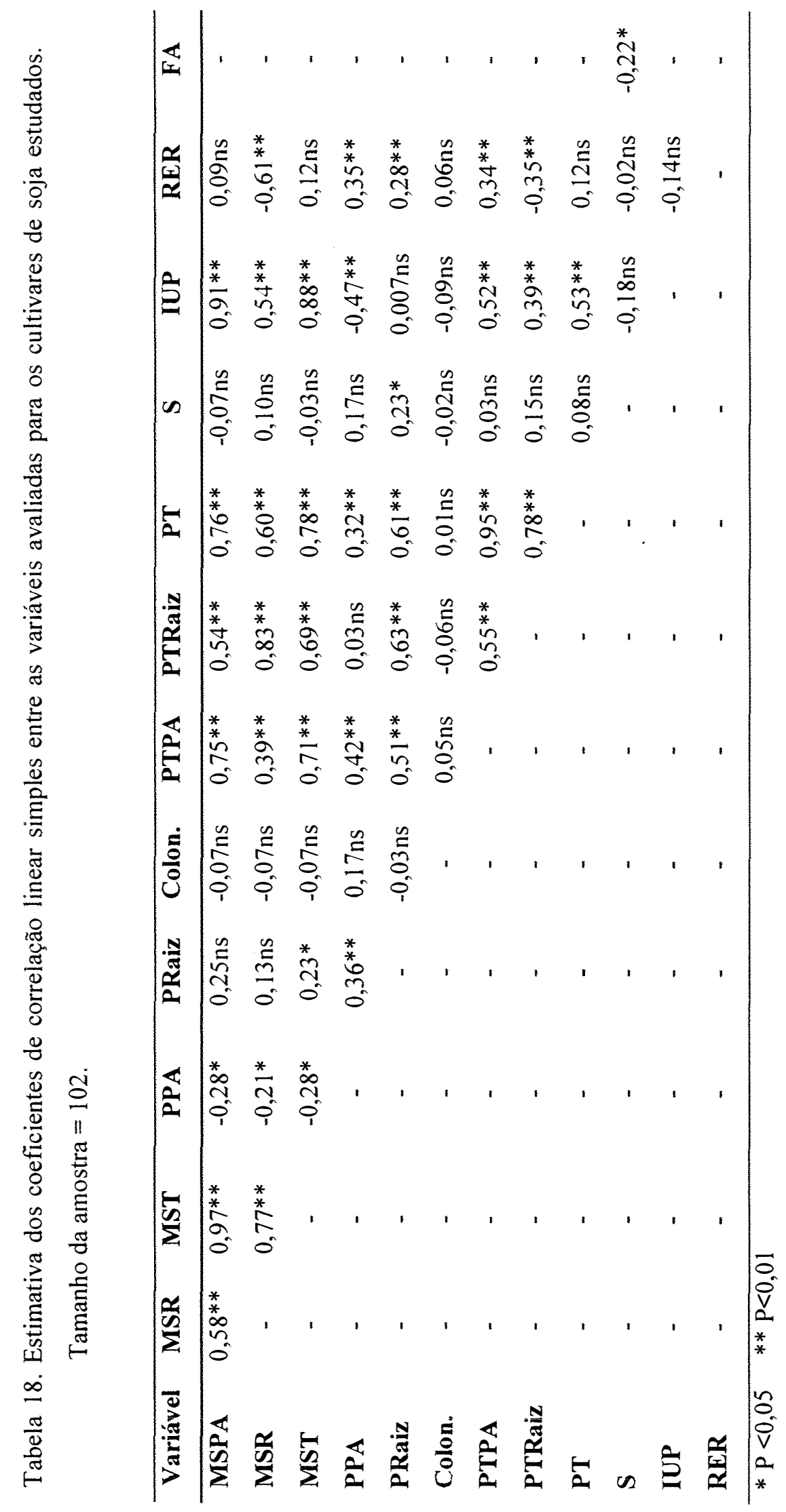


IAC PL-1 esse último não diferindo do cultivar DM-118. A partir do cultivar DM-118 houve um comportamento semelhante no IUP para os demais cultivares. O feijão guandu e o arroz apresentaram os menores índices de utilização de fósforo e em relação a grande maioria dos cultivares apresentaram baixo IUP. Os cultivares BRS 133, M-Soy 8866, IAC-18, DM-309, EMGOPA 316 e BRSGO Jataí apresentaram valores de IUP inferiores $(P<0,05)$ aos cultivares DM-Vitória, DM-118, IAC PL-1 e BRAS 97-7371. Segundo Martinez et al. (1993), genótipos de soja mais eficientes no uso de P tiveram menores relações parte aérea:raiz no nível mais baixo do elemento, indicando maior eficiência de enraizamento sob condições de baixa disponibilidade. Os cultivares estressados apresentaram eficiências nutricionais maiores produzindo maiores quantidades de matéria seca produzida por unidade de $\mathrm{P}$ disponível.

A grande variação entre os cultivares demonstra a diversidade genotípica encontrada neste experimento. Os resultados indicam diferenças na eficiência de P entre os cultivares utilizados devendo-se partir para o estabelecimento de doses crescentes de P para a confirmação desta eficiência.

Os indicadores atividade específica (S), razão de eficiência radicular (RER) e índice de utilização do fósforo (IUP) não se correlacionaram $(P<0,05)$. A busca de indicadores que possam servir nos programas de melhoramento buscando acrescentar a eficiência de absorção e utilização do $\mathrm{P}$ é ainda um desafio. A definição do tipo de ambiente onde se deseja selecionar cultivares é muito importante, senão vejamos, por exemplo, ambientes secos ou períodos de veranicos, o indicador RER que representa a relação entre o $\mathrm{P}$ acumulado na parte aérea pela biomassa da raiz, é um bom indicador pois nesse caso a planta precisa apresentar um sistema radicular desenvolvido para suportar condições de seca mesmo que seja por pequeno período de tempo. No entanto, esse indicador não apresentou resultados convincentes que viessem elucidar que cultivares poderiam ser indicados como mais eficientes na absorção de $\mathrm{P}$, talvez porque as condições do substrato tenham contribuído devido a não ter havido um estresse hídrico. Relatos de Jones et al. (1989) e Batten (1992) mencionam a razão de eficiência radicular como indicador útil em programas de seleção, contudo esse parâmetro provavelmente seja mais indicado para a cultura do trigo e não para a cultura da soja. 
A atividade específica (S) mede diretamente as diferenças entre as plantas na capacidade de absorção de $\mathrm{P}$, pelo uso do radioisótopo ${ }^{32} \mathrm{P}$. É calculada pela relação entre contagens por minuto de ${ }^{32} \mathrm{P}(\mathrm{CPM})$ e a quantidade de $\mathrm{P}$, em microgramas. Quanto menor a atividade específica significa maior eficiência em absorver o nutriente do solo menos disponível. Este indicador certamente fornece com maior grau de precisão a informação desejada com relação à eficiência de absorção e utilização de fósforo. Este indicador correlacionou-se negativamente $(P<0,08)$ com o índice de utilização de fósforo (IUP) embora tenha obtido um coeficiente baixo (- 0,18$)$. Foi determinado o coeficiente de correlação linear simples entre a enzima fosfatase ácida e atividade específica (S) obtendo-se um coeficiente negativo baixo $(-0,22)$, porém significativo ( $P$ $<0,02)$. Esses valores sugerem que, juntos, estes indicadores auxiliam na seleção de cultivares eficientes na absorção e utilização de $P$.

$\mathrm{O}$ indicador razão de eficiência radicular (RER) não forneceu esclarecimentos que se esperava para a eficiência de $\mathrm{P}$ em virtude dos resultados desencontrados (Tabela 16), onde por exemplo, cultivares que apresentaram maiores biomassas de parte aérea e raiz contrariamente, apresentaram razão de eficiência radicular baixos, convergindo apenas com a relação parte aérea : raiz e concentração de P. Além disso seus valores foram divergentes dos valores encontrados para a atividade específica (S) e índice de utilização de fósforo (IUP). Contradições deste tipo são encontradas em leguminosas são mencionadas por Araújo (2000) e precisam ser melhor investigadas. 


\section{CONCLUSÕES}

Os cultivares precoces, semiprecoces, semitardios e tardios apresentaram diferenças genotípicas na eficiência de absorção e utilização de fósforo não somente entre os grupos, mas também dentro dos grupos examinados;

Confirma-se a existência de uma relação entre a atividade da enzima fosfatase ácida com indicadores de eficiência de absorção de fósforo, notadamente a atividade específica (S);

As variáveis porcentagem de colonização micorrízica e razão de eficiência radicular não forneceram informações consistentes, pouco contribuindo na avaliação dos cultivares de soja;

Os cultivares BRAS 97-7371 e IAC PL-1 destacaram-se entre os cultivares estudados na eficiência de absorção e utilização de P. 


\section{REFERÊNCIAS BIBLIOGRÁFICAS}

AGUILAR, A. S.; DIEST, A. van. Rock-phosphate mobilization induced by the alkaline uptake pattern of legumes utilizing symbiotically fixed nitrogen. Plant and Soil, v. 61 p. 27-42, 1981.

ALEXANDER, T.; TOTH, R.; MEIER, R.; WEBER, H. C. Dynamics of arbuscule development and degeneration in onion, bean and tomato with reference to vesicular-arbuscular mycorrhizae in grasses. Canadian Journal of Botany, v. 67, p.2505-2513, 1989.

AMBROSANO, E.J.; TANAKA, R.T.; MASCARENHAS, H.A.A.; RAIJ, B.van; QUAGGIO, J.A.; CANTARELlA, H. Leguminosas e Oleaginosas. In: RAIJ, B. van (Ed.). Recomendações de adubação para o Estado de São Paulo. Campinas: Instituto Agronômico de Campinas; Fundação IAC, 1996. p.187-203.

ARAÚJO, A. P. Eficiência vegetal de absorção e utilização de fósforo, com especial referência ao feijoeiro. In: NOVAIS, R.; ALVAREZ V., V.H.; SCHAEFER, C.E.G.R. (Ed.). Tópicos em ciência do solo.Viçosa: SBCS,2000. v.1, cap.6, p.163212.

ASCENCIO, J. Acid phosphatase as a diagnostic tool. Communications in Soil Science and Plant Analysis, v. 25, p.1553-1564, 1994. 
AUNG, L.H. Root-shoot relationships: The plant root and its environment. Charlottesville: University Press of Virginia, 1974. p.29-64.

AZCON, R.; OCAMPO, J. A. Factors affecting the vesicular-arbuscular infection and mycorrhizal dependency of thirteen wheat cultivars. New Phytologist, v. 87, p.677$685,1981$.

BAILIAN, L.; McKEAND, S. E.; ALLEN, H. L. Genetic variation in nitrogen use efficiency of loblolly pine seedlings. Forest Science, v.37, p.613-626, 1991.

BARBER, S. A. Soil nutrient bioavailability: a mechanistic approach. New York: Wiley, 1995. $426 \mathrm{p}$.

BARBOSA FILHO, M. P. Transformações do fósforo em solos ácidos e sua disponibilidade para a cultura de arroz de sequeiro (Oryza sativa L.). Piracicaba, 1986. 104 p. Tese (Doutorado) - Escola Superior de Agricultura "Luiz de Queiroz", Universidade de São Paulo.

BATTEN, G.D. A review of phosphorus efficiency in wheat. Plant and Soil, v.146, p.163-168, 1992.

BECKWITH, R.S. Sorbed phosphate at standard supernatant concentration as an estimate of the phosphate needs of soils. Australian Journal Experimental Agricultural Animal Husbandry, v.5, p.52-58, 1965.

BEEVER, R, E.; BURNS, J. W. Phosphorus uptake, storage and utilization by fungi. Advance Botanic Research, v.8, p. 127-219, 1980. 
BESFORD, R. T. A phosphatase as a potencial indicator of phosphorus status of the glasshouse cucumber (Cucumis sativus). Journal of the Science, Food and Agriculture, v.29, p.87-91, 1978.

BESFORD, R. T. Quantitative aspects of leaf acid phosphatase activity and the phosphorus status of tomato plants. Annals of Botany, v. 44, p.153-161, 1979a.

BESFORD, R. T. Phosphorus nutrition and acid phosphatase activity and the leaves of seven plant species. Journal of the Science, Food and Agriculture, v. 30, p.281285, $1979 b$.

BESFORD, R. T. Nutrient imbalances in tomato plants and acid phosphatase activity in the leaves. Journal of the Science, Food and Agriculture, v. 30, p.275-280, 1979c.

BESFORD, R. T. A rapid tissue for diagnosing phosphorus deficiency in the tomato plant. Annals of Botany, v. 45, p.225-227, 1980.

BIELESKI, R. L.; FERGUSON, J. B. Physiology and metabolism of phosphate and its compounds. In: LAUCHLI, A.; BIELESKI, R. L. (Ed.). Inorganic plant nutrition. Encyclopedia of plant Physiology, New Series, Berlin: Heidelberg, Springer-Verlag, v.15a, 1983. p.422-449.

BONFANTE-FASOLO, P. Anatomy and morphology of VA mycorrhizal. In: POWELL, C.L.; BAGYARAY, D.J.(Ed.). VA Mycorrhizae. Boca Raton: CRC Press, 1984. p.5-33. 
BOVI, M. L. A.; BASSO, L. C.; TUCCI, M. L. S. Avaliação da atividade "in vivo" da fosfatase ácida e do crescimento de progênies de pupunheira cultivadas em duas doses de nitrogênio e fósforo. Revista Brasileira de Ciência do Solo, v.22, p.427434, 1998.

BRAGA, J.M. Avaliação da fertilidade do solo: análises químicas. Viçosa: Universidade Federal de Viçosa, 1980. 87p.

CÂMARA, G.M.S. (Ed.) Soja: tecnologia da produção II. Piracicaba: ESALQ/LPV, 2000. 450p.

CAMARGO, L.C.; MONIZ, A.C.; JORGE, J.A.; VALADARES, J.M.A.S. Métodos de análise química, mineralógica e física de solos do Instituto Agronômico de Campinas. Campinas: IAC, 1986. 94p. (Boletim Técnico, 106)

CHANG, S.C.; JACKSON, M.L. Fractionation of soil phosphorus. Soil Science, v.84, p.133-144, 1957.

CLARKSON, D. T. Factors affecting mineral nutrient acquisition by plants. Annual Review of Plant Physiology, v. 36, p.77-115, 1985.

COGLIATTI, D. H.; CLARKSON, D. T. Physiological changes in, and phosphate uptake by potato plants during development of, and recovery from phosphate deficiency. Physiology plantarum, v.58, p.287-294, 1983.

COX, G.; MORAM, K. J.; SANDERS, F.; NOCKOLDS, C.; TINKER, P. B. Translocation and transfer of nutrients in vesicular-arbuscular mycorrhizas. New Phytologist, v.84, p.649-659, 1980. 
CRUSH, J. R.; CARRADUS, J. R. Effect of mycorrhizas on growth of some white clovers. New Zealand Journal Agriculture Research, v. 23, p.233-237, 1980.

DI, H.J.; CAMERON, K.C.; MCLAREN, R.G. Isotopic dilution methods to determine the gross transformation rates of nitrogen, phosphorus, and sulfur in soil: a review of the theory, methodologies and limitations. Australian Journal of Soil Research, v.38, p.213-230, 2000.

DREW, M. C.; SAKER, L.R. Uptake and long-distance transport of phosphate, potassium and chloride in relation to internal ion concentration in barley: evidence of non-allosteric regulation. Planta, v.160, p.500-507, 1984.

FAGERIA, N. K. Otimização da eficiência nutricional na produção das culturas. Revista Brasileira de Engenharia Agrícola e Ambiental, v.2, p.6-16, 1998.

FARRAR, J. F.; JONES, D. L. The control of carbon acquisition by roots. New Phytologist, v.147, p.43-53, 2000.

FASSBENDER, H.W. Química de suelos com énfasis em suelos de América Latina. San José: IICA, 1986. 398p.

FERNANDES, C. Eficiências de diferentes culturas e híbridos de milho quanto à utilização de fósforo em solos de cerrado. Piracicaba, 2001. 51p. Dissertação (Mestrado) - Escola Superior de Agricultura “Luiz de Queiroz”, Universidade de São Paulo.

FERNANDEZ, D. S.; ASCENCIO, J. Acid phosphatase activity in bean and cowpea plants grown under phosphorus stress. Journal of Plant Nutrition, v.17, p.229-241, 1994. 
FNP Consultoria \& Comércio. Agrianual 2003 - Anuário da agricultura brasileira. São Paulo , 2003. 544p.

FÖHSE, D.; CLAASSEN, N.; JUNGK, A. Phosphorus efficiency of plants. I. External and internal $\mathrm{P}$ requirement and $\mathrm{P}$ uptake efficiency of different plant species. Plant and Soil, v.110, p. 101-109, 1988.

FREDEEN, A. L.; RAO, I. M.; TERRY, N. Influence of phosphorus nutrition on growth and carbon partitioning of Glycine max. Plant Physiology, v.89, p.225-230, 1989.

FURLANI, A.M.C.; MACHADO, C.T.T.; Variabilidade e herança da eficiência na absorção e utilização de nutrientes em ambientes marginais, em germoplasma de soja, trigo, arroz e milho. In: ALVAREZ V,V.H.; SCHAEFER, C.E.G.R.; BARROS, N.F.; MELlO, J.W.V.; COSTA, L.M. (Ed.). Tópicos em Ciência do Solo. Viçosa: Sociedade Brasileira de Ciência do Solo, 2002. cap.7, p.337-391.

FURLANI, A.M.C.; FURLANI, P.R.; TANAKA, R.T.; MASCARENHAS, H.A.A.; DELGADO, M.D.P.; Variability of soybean germplasm in relation to phosphorus uptake and use efficiency. Scientia Agricola, v.59, p.529-536, 2002.

GABELMAN, W. H.; GERLOFF, G. C. The search for and interpretation of genetic controls that enhance plant growth under deficiency levels of macronutrients. Plant and Soil, v.72, p.335-350, 1983.

GARDNER, W. K.; BARBER, D. A. PARBERRY, D. G. The acquisition of phosphorus by Lupinus albus L. III. The probable mechanism by which phosphorus movement in the soil/root interface is enhanced. Plant and Soil, v.70, p.107-114, 1983. 
GAHOONIA, T.; CLAASSEN, N.; JUNGK, A. Mobilization of phosphate in different soils by ryegrass supplied with ammonium or nitrate. Plant and Soil, v.140, p.241248, 1992.

GIOVANNETTI, M.; MOSSE, B. An evaluation of techniques for measuring vesiculararbuscular mycorrhizal infection in roots. New Phytologist, v.84, p.489-500, 1980.

GRAHAM, J.H.; LEONARD, R.T.; MENGE, J. Membrane-mediated decrease in root exudation responsible for phosphorus inhibition of vesicular-arbuscular mycorrhiza formation. Plant Physiology, v.68, p.548-552, 1981.

GUERRA, J.G.M.; ALMEIDA, D.L.; SANTOS, G.A.; FERNANDES, M.S. Conteúdo de fósforo orgânico em amostras de solos. Pesquisa Agropecuária Brasileira, v.31, p.291-299, 1996.

HARRISON, M. J. The arbuscular mycorrhizal symbiosis: An underground association. Trends in Plant Science, v.2, p.54-56, 1997.

HEDLEY, M. J.; NYE, P. H.; WHITE, R, E. Plant induced changes in the rhizosphere of rape (Brassica napus var. Emerald) seedlings II. Origin $\mathrm{pH}$ change. New Phytologist, v.91, p.31-44. 1982.

HELYAR, K. R. Efficiency of nutrient utilization and sustaining soil fertility with particular reference to phosphorus. Field Crops Research, v.56, p.187-195, 1998.

HEMWALL, J. B. The fixation of phosphorus by soils. Advances in Agronomy, v.9, p. 95-112, 1957. 
HEWITT, E. J.; TATHAN, P. Interaction of mineral deficiency and nitrogen source on acid phosphatase activity in leaf extracts. Journal of Experimental Botany, v.11, p.367-376, 1960.

HOCKING, P.J.; RANDALL, P.J. Better growth and phosphorus nutrition of sorghum and wheat following organic acid secreting crops. In: HORST, W. J.; SCHENK, M.K.; BÜRKERT, A. et al. Plant Nutrition - food security and sustainability of agro-ecosystems through basic and applied research. Dordrecht: Kluwer Academic, 2001. p.548-549.

HOCKING, P. J.; KEERTHISINGHE, G.; SMITH, F.W.; RANDALL, P. J. Comparation of the ability of different crop species to access poorly-available soil phosphorus. In: ANDO, T.; FUJITA, K.; MAE, T. et al. Plant Nutrition - for sustainable food production and environment. Japan: Kluwer Academic, 1997. p.305-308.

HOFFLAND, E.; Quantitative evaluation of the role of organic-acid exudation in the mobilization of rock phosphate by rape. Plant and Soil, v.140, p.279-289, 1992.

HOFFLAND, E.; FINDENEGG, G. R.; NELEMANS, J. A. Solubilization of rock phosphate by rape. 2. Local root exudation of organic acids as a response to $\mathrm{P}$ starvation. Plant and Soil, v.113, p.161-165,1989.

HUNT, R. A method of estimating root efficiency. Journal of Applied Ecology, v.10, p.157-164, 1973.

IGUE, K.; FUENTES, R.; BORNEMISZA, E. Mineralización de P-orgánico en suelos ácidos de Costa Rica. Journal of Agriculture, Food and Chemistry, v.20, p. 47-52, 1971. 
IMAS, P.; BARYOSEF, B.; KAFKAFI, U.; GRANMORE - NEUMANN, R. Phosphate induced carboxilate and proton release by tomato roots. Plant and Soil, v.191, p.35-39, 1997.

JAKOBSEN, I. Transport of phosphorus and carbon in VA mycorrhizas. In: A. Varma and B. Hock Mycorrhiza Structure, Function, Molecular Biology and Biotechnology. Berlin: Springer-Verlag. 1995. cap.4, p.297-324.

JARRELL, W.M.; , BEVERLY, R.B. The dilution effect in plant nutrition studies. Advances in Agronomy, v.34, p.197-224, 1981.

JEFFRIES, P. Uses of mycorrhizae in agriculture. Critical Review Biotechnology, v.5, p.319-357, 1987.

JESCHKE, W.; KIRKBY, E.; PEUKE, A.; PATE, J.; HARTUNE, W. Effects of P efficiency on assimilation and transport of nitrate and phosphate in intact plants of castor bean (Ricinus communis L.). Journal of Experimental Botany, v.48, p.75-91, 1997.

JONES, D. L. Organic acids in the rhizosphere - a critical review. Plant and Soil, v.205, p.25-44, 1998.

JONES, G. P. D.; BLAIR, G. J.; JESSOP, R. S. Phosphorus efficiency in wheat - a useful selection criterion? Field Crops Research, v.21, p.257-264, 1989.

KOIDE, R. T. Nutrient supply, nutrient demand and plant response to mycorrhizal infection. New Phytologist, v. 117, p.365-386, 1991. 
KOTHARI, S. K.; MARSCHNER H.; ROMHELO V. Contribution of the VA mycorrhizal hyphae in acquisition of phosphorus and zinc by maize grown in a calcareous soil. Plant and Soil, v. 131, p.177-185, 1991.

LAUCHLI, A. Soil science in the next twenty five years: does a biotechnology play a role? Soil Science Society American Journal, v.51, p.1405-1409, 1987.

LAUER, M.J.; BLEVINS, D.; SIERZPUTOWSKA-GRACZ, H 31P-Nuclear magnetic resonance determination of phosphate compartmentation in leaves of reproductive soybeans (Glycine max L.) as affected by phosphate nutrition. Plant physiology, v.89, p.1331-1336, 1989.

LEE, R. B.; RATCLIFFE, R. G. Subcellular distribution of inorganic phosphate, and levels of nucleoside triphosphate, in mature maize roots at low external phosphate concentrations: measurements with 31P NMR. Journal of Experimental Botany, v.44, p.587-598, 1993.

LYNCH, J. P.; BEEBE, S. E. Adaptation of beans (Phaseolus vulgaris L.) to low phosphorus availability. HortScience, v.30, p.1165-1171, 1995.

MARSCHNER, H. Mineral nutrition of higher plants. London: Academic Press, $1995.889 \mathrm{p}$.

MARTINEZ, H.E.P.; NOVAIS, R.F.; SACRAMENTO, L.V.S. do; RODRIGUES, L.A. Comportamento de variedades de soja cultivadas sob diferentes níveis de fósforo: II. Translocação do fósforo absorvido e eficiência nutricional. Revista Brasileira de Ciência do Solo, v. 17, p.239-244, 1993. 
McLACHLAND, K. D. Leaf acid phosphatase activity and the phosphorus status of field-grown wheat. Australian Journal of Agriculture Research, v.33, p.453-464, 1982.

McLACHLAND, K. D.; ElliOT, D. E.; DE MARCO, D. G.; GARRAN, J. H. Leaf acid phosphatase isozimes in the diagnosis of phosphorus status in field growth wheat. Australian Journal of Agriculture Research, v.38, p.1-13, 1987.

MENGEL, K.; KIRKBY, E.A. Principles of plants nutrition. Dordrecht: Kluwer Academic, 2001. 522p.

MIMURA, T. SAKANO, K.; SHIMMEN, T. Studies on the distribution, retranslocation and homeostase of inorganic phosphate in barley leaves. Plant Cell Environment, v.19, p.311-320, 1996.

MIMURA, T.; DIETZ K-J.; KAISER, W; SCHRAMM, M.; KAISER, G.; HEBER, U.; Phosphate transport across biomembranes and cytosolic phosphate homeostasis in barley leaves. Planta, v.180, p.139-146, 1990.

NEWSHAM, K. K.; FITTER, A. H.; WATKINSON, A. R. Multifunctionality and biodiversity in arbuscular mycorrhizas. Tree, v.10, p.407-411, 1995.

NOVAIS, R.F.; SMYTH, T.J. Fósforo em solo e planta em condições tropicais. Viçosa: UFV,DPS, 1999. 399p.

ORTEGA, E.; GUERREIRO, R.R. Comportamiento de las formas de fósforo y sus relaciones con la absorción de $\mathrm{P}$ por la avena, bajo tres fuentes de fertilización fosfatada en un latosol de Nariño, Colômbia. Turrialba, v.22, p. 420-430, 1972. 
OTANI, T.; AE, N.; TANAKA, H. Phosphorus (P) uptake mechanisms of crops grown in soils with low P status: II. Significance of organic acids in root exudates of pigeonpea. Soil Science and Plant Nutrition, v.42, p.553-560, 1996.

PEARSON, J. N.; JACOBSEN, I. The relative contribution of hyphae and roots to phosphorus uptake by arbuscular mycorrhizal plants, measures by dual labelling with ${ }^{32} \mathrm{P}$ and ${ }^{33} \mathrm{P}$. New Phytologist, v. 124, p.489-494, 1993.

PEREIRA, P.R.G. Estudo da eficiência de fungos micorrizicos vesicular-arbusculares para a soja em amostra de um latossolo. Viçosa, 1986. 72p. Dissertação (Mestrado) - Universidade Federal de Viçosa.

PHILLIPS, J. M.; HAYMAN, D.S. Improved procedures for clearing roots and staining parasitic and vesicular-arbuscular mycorrhizal fungi for rapid assessment of infection. Transactions of the British Mycological Society, v.55, p.158-161, 1970.

PREZZOTO, M.E.M. Fracionamento de fósforo em solos incubados com vinhaça. Piracicaba, 1979. 85p. Dissertação (Mestrado) - Escola Superior de Agricultura "Luiz de Queiroz", Universidade de Paulo.

RAIJ, B. van.; QUAGGIO, J. A. Métodos de análises de solos para fins de fertilidade. Campinas: Instituto Agronômico, 1983. 39p. (Boletim Técnico, 81)

RAJAN, S.S.S.; Phosphorus adsorption characteristics of Hawaiian soils and their relationships to equilibrium phosphorus concentrations required for maximum growth of millet. Plant and Soil, v.39, p.519-532, 1973.

RATNAYAKE, M.; LEONARD, R.T.; MENGE, J.A. Root exudation in relation to supply of phosphorus and its possible relevance to mycorrhizal formation. New Phytologist, v.81, p.543-552, 1978. 
REDEKER, D., KODNER, R.; GRAHAM, L. Glomalian fungi from the Ordovician. Science, v.289, p.1920-1921, 2000.

RILEY, D; BARBER, S. A. Effect of ammonium and nitrate fertilization on phosphorus uptake as related to root-induced $\mathrm{pH}$ changes at the root-soil interface. Soil Science Society American Proceedings, v.35, p.301-306, 1971.

RORINSON, I. H. The response to phosphorus of some ecologically distinct plant species. I Growth rates and phosphorus absorption. New Phytologist, v.67, p.913$923,1968$.

RYAN, P. R.; JONES, D. L.; DELHAIZE, E. Function and mechanism of organic acid exudation from plant roots. Annual Review of Plant Physiology and Plant Molecular Biology, v.52, p.527-560, 2001.

SANDERS, F. E.; TINKER, P. B. Mechanism of absorption of phosphate from soil by Endogone mycorrhizas. Nature, v.233, p.278-279, 1971.

SARRUGE, J.R.; HAAG, H.P. Análises químicas em plantas. Piracicaba: ESALQ, 1974. $56 \mathrm{p}$.

SAS INSTITUTE. SAS/STAT user's guide. version 6.11., 4.ed., v.2, Cary, SAS, 1996. $842 \mathrm{p}$.

SCHACHTMAN, D. P.; REID, R. J.; AYLING, S. M. Phosphorus uptake by plants: From Soil to Cell. Plant Physiology, v.116, p.447-453, 1998.

SCIVITTARO, W. B. Eficiência agronômica de fertilizantes fosfatados fluidos e sólidos. Piracicaba. 1993. 111 p. Dissertação (Mestrado) - Centro de Energia Nuclear na Agricultura, Universidade de São Paulo. 
SCOTT RUSSEL, R.; RUSSEL, E. W.; MARAIS, P. G. Factors affecting the ability of plants to absorb phosphate from soil. II A comparison of the ability of diferent species to absorb labile soil phosphate. Journal of Soil Science, v.9, p.101-108, 1958.

SHAH, P. KAKAR, K. M.; ZADA. Phosphorus use-efficiency of soybean as affected by phosphorus application and inoculation. In: HORST, W. J.; SCHENK, M.K.; BÜRKERT, A.; et al. Plant Nutrition - food security and sustainability of agroecosystems through basic and applied research. Dordrecht: Kluwer Academic. 2001. p.670-671.

SIDDIQI, M.Y.; GLASS, A.D. Utilization index: a modified approach to the estimation and comparison of nutrient utilization efficiency in plants. Journal of Plant Nutrition, v.4, p.289-302, 1981.

SILVA, F. C. da; BASSO, L. C. Avaliação da atividade in vivo da fosfatase ácida da folha na diagnose da nutrição fosfórica em cana-de-açúcar. Revista Brasileira de Ciência do Solo, v.17, p.371-375, 1993.

SMITH, S. E.; READ, D. J. Mycorrhizal symbiosis. San Diego: Academic Press, 1997. 605p.

SMITH, S. E.; GIANINAZZI-PEARSON, V. Physiological interactions between symbionts in vesicular-arbuscular mycorrhizal plants. Annual Review of Plant Physiology and Plant Molecular Biology, v. 39, p.221-244, 1988.

SMITH, F.A.; SMITH, S. E. Structural diversity in (vesicular)-arbuscular mycorrhizal symbioses. New Phytologist, v. 137, p. 373-388, 1997. 
SMITH, S. E.; ROBSON, A. D.; ABBOTT, L. K. The involvement of mycorrhizas in assessment of genetically dependent efficiency of nutrient uptake and use. Plant and Soil, v.146, p.169-179, 1992.

SMITH, S. E.; DICKSON, S.; SMITH, F.A. Nutrient transfer in arbuscular mycorrhizas: How are fungal and plant processes integrated ? Australian Journal of Plant Physiology, v. 28, p.683-694, 2001.

SMITH, S. E.; St. JOHN B. J.; SMITH, F.A.; BROMLEY, J. L. Effect of mycorrhizal infection on plant growth, nitrogen and phosphorus nutrition of glasshouse-grown Allium cepa L. New Phytologist, v. 103, p. 359-373, 1986.

STEVENSON, F.J. Cycles of soil: carbon, nitrogen, phosphorus, sulfur, micronutrients. New York: John Wiley, 1986. 380p.

STRIBLEY, D. P.; TINKER, P.B; RAYNER, J. H. Relation of internal phosphorus concentration and plant weight in plants infected by vesicular-arbuscular mycorrhizas. New Phytologist, v.86, p.261-266, 1980.

STRÖM, L. Root exudation of organic acids: importance to nutrient availability and the calcifuge and calcicole bahaviour of plants. Oikos, v.80, p.459-466, 1997.

STRÖM, L.; OLSSON, T.; TYLER, G. Differences between calcifuges and acidifuges plants en root exudation of low molecular weight organic-acids. Plant and Soil, v.167, p.239-245, 1994.

STRÖM, L.; OWEN, A. G.; GODBOLD, D. L.; JONES, D. L. Organic acid mediated P mobilization in the rhizosphere and uptake by maize roots. Soil Biology and Biochemistry, v.34, p.703-710, 2002. 
TANAKA, R.T.; MASCARENHAS, H.A.A. Soja: Nutrição, correção do solo e adubação. Campinas: Fundação Cargill, 1992. 60p.

THEODOROU, M. E.; PLAXTON, W. C. Metabolic adaptations of plant respiration to nutritional phosphate deprivation. Plant Physiology, v.101, p.339-344, 1993.

VAN DER HEIJDEN, M. G. A.; KLIRONOMOS, J. N.; URSIC, M.; MOUTOGLIS, P.; STREITWOLF-ENGEL, R.; BOLLER, T.; WIEMKEN, A.; SANDERS, I. R. Mycorrhizal fungal diversity determines plant biodiversity, ecosystem variability and productivity. Nature, v.396, p.69-72, 1998.

VITTI, G.C.; TREVISAN, W. Manejo de macro e micronutrientes para alta produtividade da soja. In: CÂMARA, G.M.S. Soja: tecnologia da produção II. . Piracicaba: ESALQ/LPV, 2000. cap.17, p.383-422.

VOLKWEISS, S.J.; RAIJ, B. Retenção e disponibilidade de fósforo em solos. In: SIMPÓSIO SOBRE O CERRADO, 4., Brasília, 1976. Bases para utilização agropecuária. Belo Horizonte: Itatiaia,1977. p.317-332.

WOOLHOUSE, H.W. Membrane structure and transport problems considered in relations to phosphorus and carbon movements and carbon movements and the regulations of endotrophic mycorrhizal associations. In: SANDERS, F.E.; MOSSE, B.; TINKER, P.B. (Ed.). Endomycorrhizas. London: Academic Press, 1975. p.209-240.

YAN, X.; LYNCH, J. P.; BEEBE, S. E. Genetic variation for phosphorus efficiency of common bean in contrasting soil types: I. Vegetative response. Crop Science, v.35, p.1086-1093, 1995. 
YUAN, T. L.; ROBERTSON, W. K.; NELLER, J.R. Forms of newly fixed phosphorus in three sandy soils. Soil Science Society of America Proceedings, v.24, p.447$450,1960$.

ZAINI, Z.; MERCADO, T. T. Phosphorus and phosphatase activity of rice seedling. I Levels of phosphorus and phosphatase activity of the roots. The Philippine Agriculturist, v. 68, p.211-216, 1985.

ZHU, Y. G.; SMITH, F. A.; SMITH, S. E. Phosphorus efficiencies and their effects on $\mathrm{Zn}, \mathrm{Cu}$ and $\mathrm{Mn}$ nutrition of different barley (Hordeum vulgare) cultivars grown in sand culture. Australian Journal of Agricultural Research, v.53, p.211-216, 2002. 